\title{
The Relation between Fructose-Induced Metabolic Syndrome and Altered Renal Haemodynamic and Excretory Function in the Rat
}

\author{
Mohammed H. Abdulla, ${ }^{1}$ Munavvar A. Sattar, ${ }^{1}$ and Edward J. Johns ${ }^{2}$ \\ ${ }^{1}$ School of Pharmaceutical Sciences, Universiti Sains Malaysia, Minden, 11800 Penang, Malaysia \\ ${ }^{2}$ Department of Physiology, Western gateway Building, University College Cork, College Road, Cork, Ireland \\ Correspondence should be addressed to Mohammed H. Abdulla, mdapharm78@yahoo.co.uk and \\ Edward J.Johns, e.j.johns@ucc.ie
}

Received 18 February 2011; Revised 30 April 2011; Accepted 15 May 2011

Academic Editor: Frank Park

Copyright (c) 2011 Mohammed H. Abdulla et al. This is an open access article distributed under the Creative Commons Attribution License, which permits unrestricted use, distribution, and reproduction in any medium, provided the original work is properly cited.

This paper explores the possible relationships between dietary fructose and altered neurohumoral regulation of renal haemodynamic and excretory function in this model of metabolic syndrome. Fructose consumption induces hyperinsulinemia, hypertriglyceridaemia, insulin resistance, and hypertension. The pathogenesis of fructose-induced hypertension is dubious and involves numerous pathways acting both singly and together. In addition, hyperinsulinemia and hypertension contribute significantly to progressive renal disease in fructose-fed rats. Moreover, increased activity of the renin-angiotensin and sympathetic nervous systems leading to downregulation of receptors may be responsible for the blunted vascular sensitivity to angiotensin II and catecholamines, respectively. Various approaches have been suggested to prevent the development of fructose-induced hypertension and/or metabolic alteration. In this paper, we address the role played by the renin-angiotensin and sympathetic nervous systems in the haemodynamic alterations that occur due to prolonged consumption of fructose.

\section{Fructose-Feeding as a Model of Metabolic Syndrome}

Metabolic syndrome or "syndrome X" is a cluster of pathologies comprising insulin resistance, hyperinsulinemia, hypertriglyceridemia, accelerated atherosclerosis, and hypertension $[1,2]$ and is associated with morbidities such as increased risk of developing cardiovascular disease, Type 2 diabetes mellitus, and renal disease [3-7]. Previous studies have shown that the fructose-fed rat model develops an insulin-resistance syndrome with a very similar metabolic profile to the human condition, including hyperinsulinemia, insulin resistance, hypertriglyceridemia, and decreased HDL cholesterol $[8,9]$. Consequently, the administration of a fructose-rich diet has been used as a model for investigating the development of the metabolic syndrome [10]. Variable amounts of fructose and modes of intake have been utilized which have resulted in the expression of a range of features of the metabolic syndrome. Sánchez-Lozada et al. [11] administrated fructose either in the drinking water or as a dietary component and induced hypertension, hyperuricemia, and hypertriglyceridemia [11]. However, fructose in the feed was found to result in a more severe metabolic syndrome and kidney damage compared to fructose given in the drinking water which suggested a relationship between the amount of fructose consumed and the development of deleterious effects [11]. This was supported by a previous study in the rat which proposed that fructose-induced hypertension was concentration and time dependent [12]. It is evident from these reports that the fructose model can be a useful tool for studying various aspects of metabolic syndrome by manipulating routes, amounts, and lengths of exposure to fructose which may have applicability to the human situation as the metabolic syndrome develops. Table 1 shows the various routes of fructose administration and different feeding periods.

\section{Fructose Consumption and Energy Intake}

Fructose is a natural sugar found in many fruits and honey and is commonly used as a sweetener. Because high dietary 
TABLE 1: The effect of different routes of fructose administration in different species over different time periods.

\begin{tabular}{|c|c|c|c|c|c|}
\hline $\begin{array}{l}\text { Method of } \\
\text { administration }\end{array}$ & Species & Amount* & Length of study & Effect & Reference \\
\hline \multirow[t]{10}{*}{ Drinking } & Mouse & $10 \%$ & 3 weeks & -Hypertension, hyperinsulinemia & {$[13]$} \\
\hline & Rat & $10 \%$ & 8 weeks & -Hypertension, hypertriglyceridemia & {$[11]$} \\
\hline & & & 5 weeks & -Hypertension, insulin resistance & {$[14]$} \\
\hline & & & $6-19$ days & -Hypertriglyceridemia & {$[15]$} \\
\hline & & $20 \%$ & $\begin{array}{l}8 \text { weeks } \\
30 \text { days }\end{array}$ & $\begin{array}{l}\text {-Hypertension, hyperglycemia, } \\
\text { hyperinsulinemia }\end{array}$ & {$[16]$} \\
\hline & & & & -Impaired glucose tolerance, dyslipidemia & {$[17]$} \\
\hline & & $60 \%$ & 2 weeks & Hyperglycemia & {$[18]$} \\
\hline & Hamster & $10 \%, 20 \%$ & 2, 4 and 6 months & Hyperglycemia, hyperinsulinemia & [19] \\
\hline & guinea pigs & $10 \%$ & 6-19 days & Hypertriglyceridemia & {$[15]$} \\
\hline & & $10 \%$ & 18 weeks & Hyperglycemia & {$[20]$} \\
\hline \multirow[t]{10}{*}{ Food } & Mouse & $60 \%$ & 8 weeks & $\begin{array}{l}\text {-Hypertension, impaired glucose tolerance, } \\
\text { dyslipidemia }\end{array}$ & {$[21]$} \\
\hline & Rat & $60 \%$ & 8 weeks & -Hypertension, hypertriglyceridemia & [11] \\
\hline & & & 6 weeks & -Hyperinsulinemia, hypertriglyceridemia & {$[22]$} \\
\hline & & $66 \%$ & 4 weeks & -Hyperinsulinemia & [23] \\
\hline & & & 2 weeks & $\begin{array}{l}\text {-Hypertension, hyperinsulinemia, } \\
\text { hypertriglyceridemia }\end{array}$ & [24] \\
\hline & & & 4 weeks & -Hyperglycemia & {$[18]$} \\
\hline & Hamster & $60 \%$ & 2 weeks & -Hyperinsulinemia, hypertriglyceridemia & {$[25]$} \\
\hline & Dog & $60 \%$ & 20-28 days & $\begin{array}{l}\text {-Hypertension, insulin resistance, } \\
\text { hyperinsulinemia, hypertriglyceridemia }\end{array}$ & [26] \\
\hline & Human & $15 \%$ & 5 weeks & -Hyperinsulinemia, hyperglycemia & {$[27]$} \\
\hline & & $20 \%$ & 5 weeks & -Hypertriglyceridemia & {$[28]$} \\
\hline
\end{tabular}

* Percentage is (weight/volume) for drinking form and (weight/weight) for food form.

fructose intake does not result in a significant weight gain, the fructose-fed rat model can be used to investigate the relationship between metabolic alterations and the development of hypertension without the confounding influences of obesity or genetic predispositions. Although the absence body weight gain has been reported in a considerable number of studies in rats [24, 29-34] and dogs [26], there have been reports of weight gain in rodents $[12,16$, $35-37]$ and in human $[38,39]$. One possible reason for these conflicting findings is that fructose was introduced at different stages of maturity and with different effects on weight gain. This is supported by the view that in this model, the younger animals gain more weight than the older ones [40]. Moreover, fructose through its suppression of leptin, a hormone that produces the sensation of satiety [41], could induce an increase in caloric intake and thereby weight gain. However, there are reports that fructose feeding increases fasting plasma level of leptins in rats [42-45] and in humans [46], or even produced no change [47]. An increase in plasma levels of leptin could be taken to indicate resistance to its action [48], and interestingly leptin resistance has been reported in rats even though plasma leptin levels may be unchanged [47]. This change in energy metabolism has been linked to hypertriglyceridemia in this model $[42,49,50]$. It is therefore evident that, whatever the underlying mechanism, a direct relationship exists between high dietary fructose intake and increased weight gain associated with higher energy consumption in this model.

\section{Fructose Consumption and Insulin Resistance}

Insulin stimulates glucose uptake, increases glycogen synthesis, and decreases gluconeogenesis and if the hormone is unable to elicit these actions, insulin resistance is said to exist and results in increased plasma insulin levels [51-53]. The hyperinsulinemia associated with insulin resistance has been found in fructose-fed rat $[16,54-57]$ and has been linked to hypertension development in this model $[1,58,59]$. Hepatic insulin resistance has also been reported following fructose consumption in humans [60]. One possible explanation for insulin resistance in fructose-fed rats is a downregulation of insulin receptors with lower insulin receptor mRNA levels in skeletal muscle but not kidney. This effect has been found to be associated with a decreased insulinstimulated glucose utilization and a reduction in insulin sensitivity [61]. Nakagawa et al. [62] reported that fructose feeding for 10 weeks not only induced hyperinsulinemia and hypertriglyceridemia but also hyperuricemia in rats. Interestingly, fructose has the property of inducing high plasma levels of uric acid [63]. This effect was reported 
to be a result of fructose metabolism, in that it undergoes phosphorylation by the enzyme fructokinase (also called ketohexokinase) into fructose-1-phosphate using ATP as a phosphate donor. However, unlike glucokinase and phosphofructokinase, which are involved in glucose metabolism, fructokinase lacks the negative feedback mechanism that prevents its action. The end result is in an accumulation of the phosphorylated substrate and therefore depletion of hepatic ATP with a consequent increase in the degradation of nucleotides to uric acid [64]. Furthermore, the insulin resistance induced by fructose intake appears to be mediated by the elevated uric acid levels $[62,65]$. It would seem that uric acid inhibits endothelial function by impairing nitric oxide (NO) induced vasodilation which is necessary for insulin to stimulate glucose uptake into the tissues. This effect of uric acid on endothelial function has also been reported in the human [66]. It has been widely reported that treating fructose-fed rats with uric acid lowering agents (Table 2) decreased plasma insulin levels, enhanced insulin sensitivity, and decreased blood pressure [62, 67]. There is general agreement that insulin resistance/hyperinsulinemia are the most important features of metabolic syndrome and indeed, metabolic syndrome sometimes is referred to as a state of insulin resistance. This may be due to the association of insulin resistance with other manifestations of the metabolic syndrome especially hypertension. However, it may be that other features yet unidentified are also important.

\section{Fructose Consumption and Hypertension}

Hwang et al. [24] initially reported that hypertension could be induced by feeding a fructose-rich diet, and this was supported by subsequent studies demonstrating a link between dietary fructose intake and elevation in blood pressure [12, $16,24,67]$. The fructose-induced elevation in blood pressure was found concomitantly to produce insulin resistance, hyperinsulinemia [59, 92], and hypertriglyceridemia [93]. Insulin resistance and compensatory hyperinsulinemia may act as predisposing factors for the development of hypertension possibly through activation of the sympathetic nervous system (SNS) [94]. This relationship between insulin resistance and hypertension has been reported in rodents $[59,95,96]$ as well as human $[97,98]$ and interventions that prevented insulin resistance in this model also normalized blood pressure $[33,57,59,76,99]$. There is an indication that this action of fructose is time and concentration dependent with one week or longer of $10 \%$ fructose in drinking water (equivalent to a diet containing $48-57 \%$ fructose) being sufficient to induce an elevation in blood pressure in the rat [12]. Insulin has been found to chronically activate the sympathetic nervous system and cause an increased peripheral vascular tone leading to an elevation in blood pressure. A consequence is that activation of the sympathetic nervous system may contribute to insulin resistance by causing a vasoconstriction that leads to a decreased blood flow and therefore decreased delivery of glucose to the tissues [100-102]. Another possibility is that renal sodium reabsorption induced by the increased sympathetic activity [103], arising from the insulin resistance, contributes to the development of hypertension. It is therefore evident from all these studies that a causal relationship between insulin resistance/hyperinsulinemia and hypertension exists in the fructose-rich diet model, with the sympathetic nervous system potentially playing an important role in both the development of hypertension and insulin resistance.

\section{Mechanism of Fructose-Induced Hypertension}

Although a number of studies have linked fructose feeding with hypertension $[8,16,24,33,104,105]$, there are other reports that have not observed an increased blood pressure in this model $[32,71,106,107]$. This conflict has been attributed to either dietary composition [108, 109], differences in animal age or strain [71], or the different techniques used to measure blood pressure $[32,107,110]$. There is uncertainty regarding the exact mechanisms by which fructose consumption produces an increased blood pressure, but several possibilities have been proposed (Figure 1) including increased sympathetic nervous system activity $[21,72,111]$, elevated circulating catecholamines [112], enhanced renin-angiotensin system activity and Ang II levels [112, 113], increased sodium reabsorption [114], impaired endothelium-dependent relaxation $[9,115,116]$, and increased secretion of endothelin-1 (ET-1) [92, 117, 118]. All of these factors may contribute to an increased vascular tone and impaired endothelial function. Furthermore, there is evidence that hyperinsulinemia itself causes hypertension as long-term insulin administration causes an increased blood pressure in rats $[96,119]$ which is reversed upon discontinuation of the insulin [120]. A further suggestion has been that $\mathrm{Na}^{+} / \mathrm{H}^{+}$exchanger activity is increased in association with hyperinsulinemia following chronic fructose intake [121]. In addition, Catena and coworkers [61] have shown the antinatriuretic effect of hyperinsulinemia is determined by a mechanism that depends on the number of insulin receptors in the tissues, and this density is inversely related to dietary salt intake. Therefore, under conditions of long-term high salt intake together with elevated fructose feeding, the control mechanism for sodium balance will be deranged [61]. The combined effect of fructose and salt has been further investigated, and long-term vascular effects contributing to hypertension have been reported [122]. A raised dietary fructose intake can also enhance the absorption of sodium chloride from the gastro-intestinal tract by increasing the activity of the Glut5 (Slc2a5) transporter in the gut [123]. Furthermore, a recent study in mice showed that the Glut 5 transporter was responsible for fructose absorption from the intestine and its enhanced activity could contribute to the development of hypertension [124]. Thus far, many studies have investigated various mechanisms that may be responsible for the development of high blood pressure due to fructose consumption but whether blood pressure changes significantly in this model remains under debate. 
TABLE 2: The effect of various interventions on fructose-induced hypertension and insulin resistance in rat.

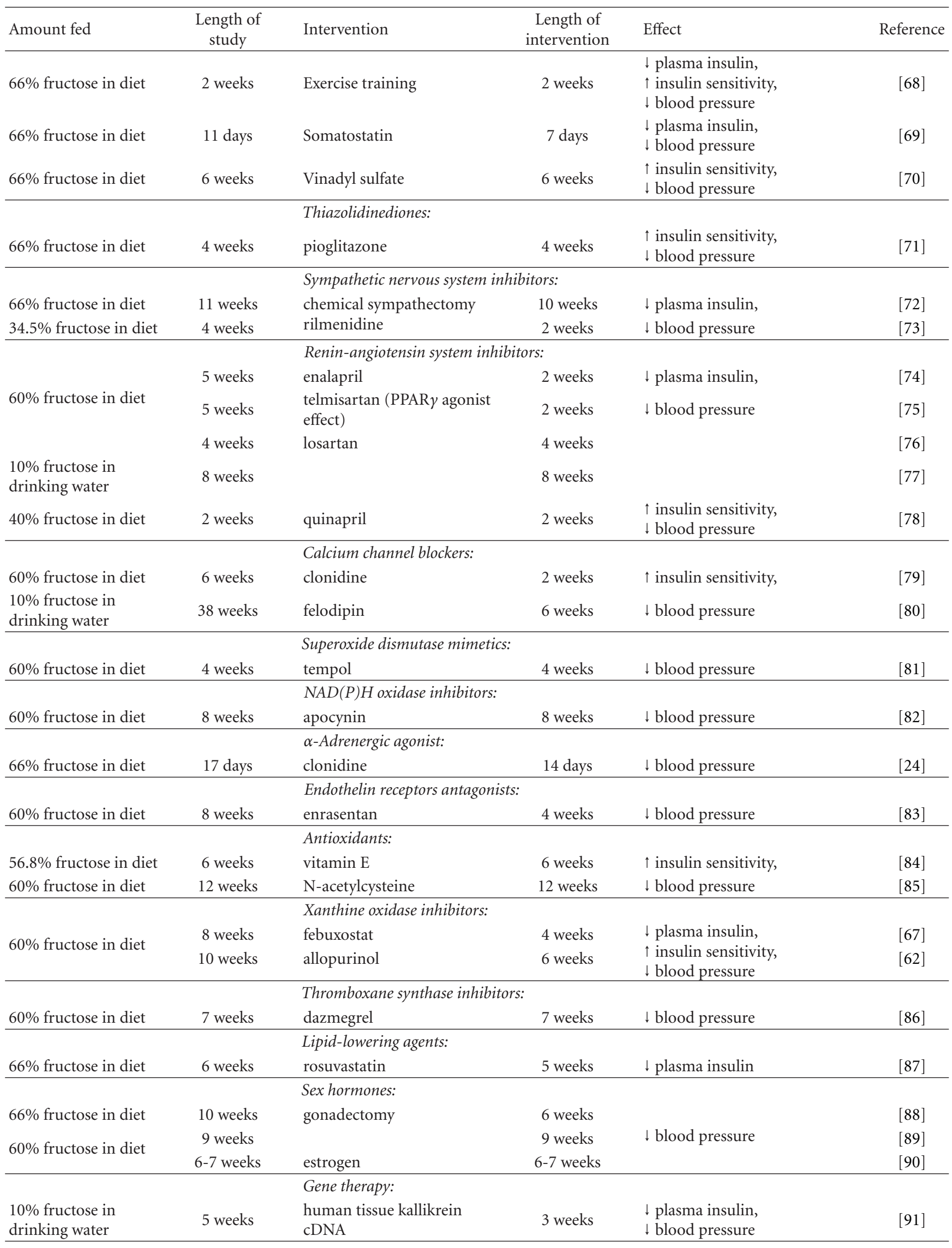

$\uparrow$ indicates increase; $\downarrow$ indicates decrease. 


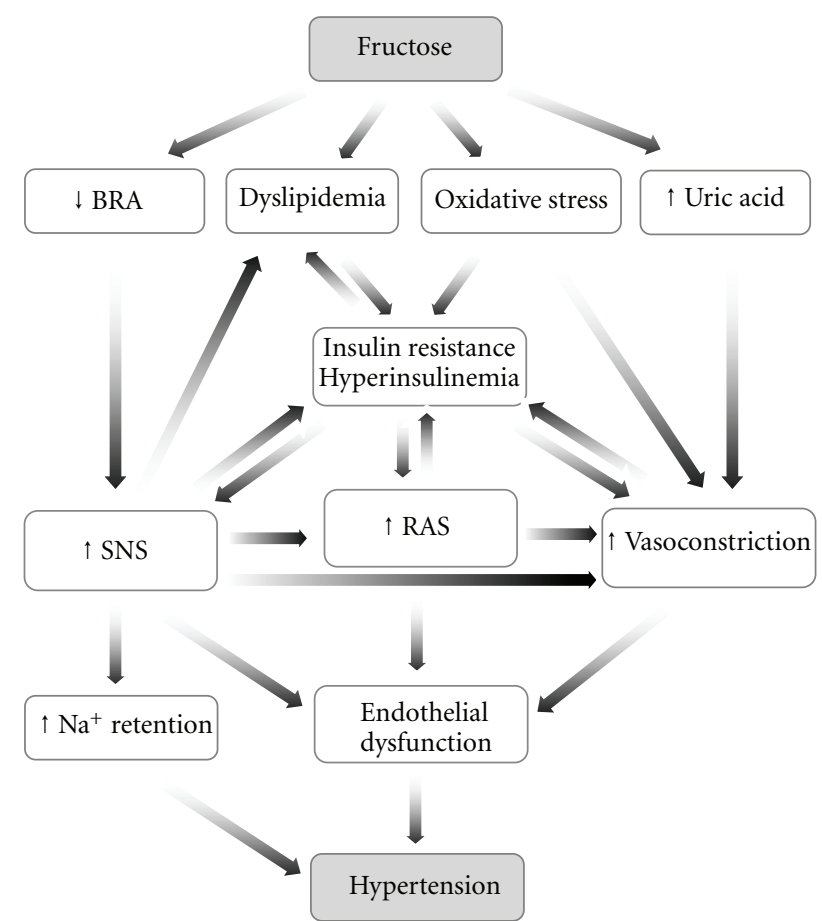

FIGURE 1: The proposed mechanisms by which fructose feeding results in hypertension. BRA: baroreflex sensitivity; SNS: sympathetic nervous system; RAS: renin-angiotensin system.

\section{Fructose Consumption and Vascular Dysfunction}

The vascular system is important for the delivery of nutrients and hormones to the tissues and consequently any impairment in vascular responsiveness may contribute to insulin resistance $[51,52,100]$. On the other hand, insulin resistance and hyperinsulinemia in fructose-fed rats impair endothelial function and thereby contribute to the elevated blood pressure in this model [125]. Vascular dysfunction due to a fructose-rich diet has been reported in the rat $[116,126]$, and it is recognized that vascular dysfunction in metabolic syndrome is associated with increased vasoconstrictor sensitivity [127] and production of vascular superoxide anions [128-130]. In addition, impaired endothelium-dependent relaxation has been found to occur after chronic fructose intake in mice [131] and rats $[116,118,128,132,133]$. There is now evidence that insulin modulates the expression of endothelial nitric oxide synthase enzyme (eNOS) and stimulates nitric oxide (NO) production causing vasodilation $[134,135]$. However, in states of insulin resistance, the effects on eNOS and NO were blunted resulting in impaired endothelium-dependent relaxation $[126,136,137]$. Thus, it is possible that this blunted vascular action of insulin in itself can contribute to and exacerbate the development of insulin resistance [51, 52, 101]. Furthermore, there is evidence in mesenteric vessels that long-term fructose-feeding is associated with an impairment of $\alpha_{2}$-adrenergic-mediated relaxation which is dependent on NO. In other studies using aortae of fructose-fed rats, endothelium-dependent relaxation was decreased [138]. Thus, an impaired endothelialdependent vasodilatory mechanism may also be involved in the development of hypertension in this model [125]. From all these findings, it is apparent that endothelial dysfunction in metabolic syndrome is related to the presence of insulin resistance/hyperinsulinemia which results not only in an enhanced vascular tone but also in blunted vasodilatory mechanisms.

\section{Fructose Consumption and Oxidative Stress}

Fructose-feeding in rats has been found to increase oxidative stress as reflected by the generation of reactive oxygen species that play a key role in the cardiovascular abnormalities associated with insulin resistance [130]. There is evidence that treatment with antioxidants, such as vitamin E, improves insulin resistance in fructose-fed rats [84], while the oxidative damage brought about by dietary fructose is due to a defect in the antioxidant defense mechanism and increased free radical production [139]. There is an elevation in lipid peroxidation when assessed by the increased plasma levels of malonyldialdehyde (MDA) and decreased plasma glutathione (GSH) $[84,130,140,141]$. Excess superoxide radical $\left(\mathrm{O}_{2}{ }^{-}\right)$is produced in the vasculature of rats with insulin resistance which in turn can degrade $\mathrm{NO}$ and enhance the generation of other reactive oxygen species which are responsible for lipid peroxidation and therefore vascular damage [128, 133]. Based on these findings, it has been suggested that taurine, a sulphur-containing amino acid, is capable of decreasing oxidative stress and improving insulin sensitivity in fructose-fed rats $[142,143]$. This amino acid is a derivative of the sulfur-containing amino acid cysteine, which is the precursor of GSH and has been reported to be available in excitable tissues and cells. Furthermore, Korandji et al. [138] have reported that the level of asymmetric dimethylarginine (ADMA), an endogenous modulator of endothelial function and oxidative stress, is high in fructosefed rats. This increase in ADMA is possibly due to the increased oxidative stress and associated hypertension in this model. Therefore, oxidative stress due to fructose-feeding is associated with higher levels of lipid peroxides and other reactive substances in the presence of a defective antioxidant system.

\section{Effect of Fructose Feeding on Adrenergic and Ang II Control of Renal Vascular Tone}

The effects of fructose-induced metabolic syndrome on the functional contribution of $\alpha_{1}$-adrenoceptor-mediated vasoconstriction of resistance vessels have not been fully elucidated, and there is conflicting data regarding whether it is associated with an enhancement [145] or inhibition $[16,131]$ of adrenergically induced renal vasoconstrictions. Fructose feeding attenuated the vascular contractile responses to noradrenaline in vitro which was mainly due to higher GTP-binding protein activity which is coupled to $\alpha_{2}$-adrenoceptors on the vascular endothelium [131]. A 


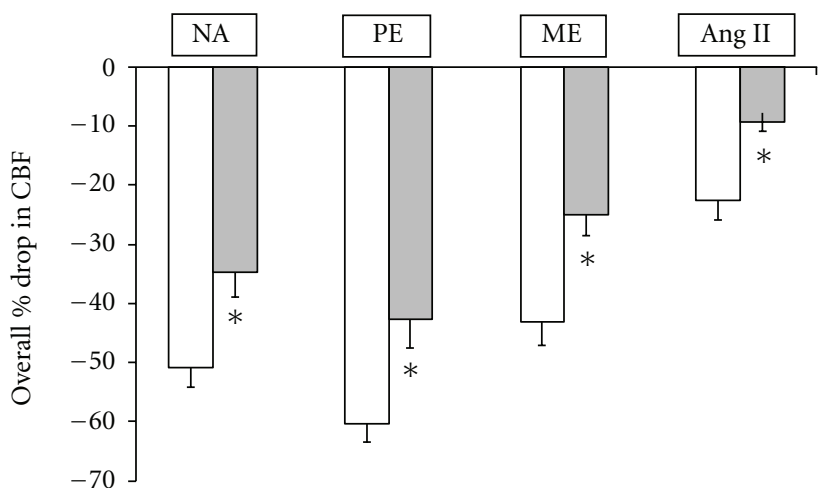

$\square$ Control
$\square$ Fructose-fed

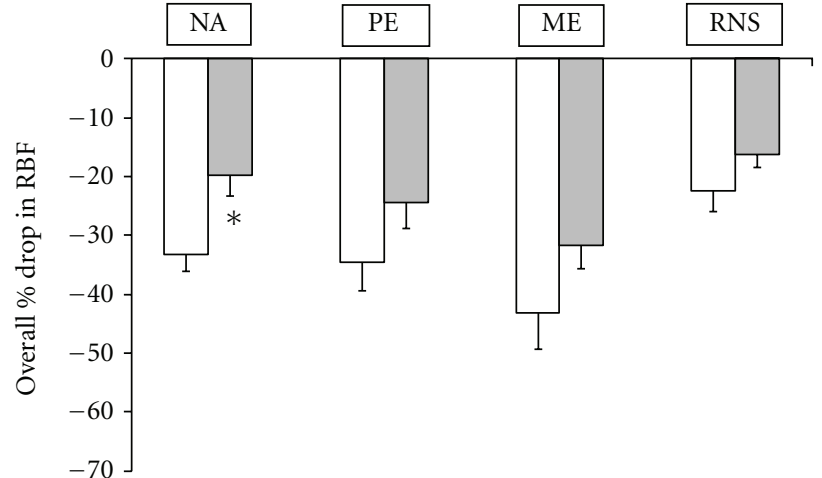

(b)

FIgURE 2: (a) The effect of fructose-feeding on the renal vascular responses to adrenergic agonists and Ang II. The vascular responses, as assessed by the reduction in renal cortical blood flow (CBF) due to adrenergic agonists or Ang II intra-arterial administration (see methods), were significantly lower in fructose-fed (the gray square) compared to control (the white square) animals. (b) The effect of streptozotocininduced diabetes on the renal vascular responses to adrenergic agonists and renal nerve stimulation. The vascular response to adrenergic stimuli as assessed by reduction in total renal blood flow (RBF) due to renal vasoconstriction was slightly lower although significant only for noradrenaline in diabetic (the gray square) compared to nondiabetic (the white square) rats. Figures are reproduced from Abdulla et al. [16] and Armenia et al. [144] respectively. Data, mean \pm SEM represent the overall mean of responses to a range of doses from each agonist. Statistical analysis was performed by unpaired $t$-test for comparing between two groups each time, $*$ is $P<0.05$ of fructose-fed versus control in (a) or diabetic versus nondiabetic in $(b),(n=6)$. NA: Noradrenaline; PE: phenylephrine; ME: methoxamine; RNS: renal nerve stimulation.

reduction in the vascular sensitivity to catecholamines due to receptor desensitization has been proposed as a compensatory mechanism resulting from increased sympathetic nervous system activity $[146,147]$. In support of this notion, studies from our laboratory have shown that adrenergicand Ang II-mediated renal vasoconstrictions were attenuated in fructose-fed rats [16] (Figure 2(a)). In addition, using another model of metabolic syndrome, we reported that the streptozotocin-induced diabetic rats had attenuated responses to adrenergic stimulation [144] (Figure 2(b)). One explanation for the reported blunted renal vasoconstrictor responses to Ang II and adrenergic agonists is the higher circulating levels of Ang II and noradrenaline and raised urinary excretion of noradrenaline in fructose-fed rats [112, 113]. Impaired vascular responses to exogenously administered noradrenaline, but not Ang II, have been reported in fructose-fed rats both in vivo and in vitro. The suggestion has been made that the vasculature may have adapted to the increased sympathetic activity present in this model [148]. It is acknowledged that an increased sympathetic nervous system activity could blunt the responses to exogenously administered noradrenaline as a consequence of downregulation of adrenoceptors [146]. Another explanation for the attenuated adrenergic responses may be a compensatory mechanism to induce structural or functional changes that precede hypertension in the vasculature of diet-induced hypertension model as previously mentioned [148]. The ability of insulin to hyperpolarize vascular smooth cells through the activation of the $\mathrm{Na}^{+}, \mathrm{K}^{+}$-ATPase pump, thereby decreasing $\mathrm{Ca}^{2+}$ influx via voltage-operated channels, may also underlie the blunted vascular responses to exogenously administered noradrenaline [149, 150]. Indeed, Khan et al. [150] have reported that insulin inhibits extracellular $\mathrm{K}^{+}$- and agonist-induced contractions of vascular smooth muscle cells and attenuates the intracellular $\mathrm{Ca}^{2+}$ transient in agonist-stimulated cells. However, in the rats that naturally develop insulin resistance, the sensitivity of $\alpha_{1}$-adrenoceptormediated arteriolar vasoconstriction was increased after the onset of insulin resistance [151]. Furthermore, in the fructose-induced insulin resistance condition, there is a pronounced vascular dysfunction associated with increased vasoconstrictor sensitivity [127], as insulin is well known to exert multiple effects on vascular tone. In humans, insulin was shown to increase the cardiovascular response to noradrenaline but not to Ang II [152], but, it has also been reported that intra-arterial insulin infusion attenuates vascular reactivity to phenylephrine and Ang II [153]. In addition, in vitro studies revealed that insulin attenuated noradrenaline and Ang II induced vasoconstriction in the rabbit femoral artery [154] and rat tail artery [155]. In a prediabetic obesity model, Stepp et al. [156] reported increased renal vasoconstrictor sensitivity to Ang II in Zucker rats although this was possibly secondary to an impaired baroreflex mechanism due to altered sympathetic modulation of vascular resistance in this model [157]. However, in this same study, there was no change in the renal vasoconstrictor response to Ang II due to fructosefeeding which indicated that insulin resistance may not be a cause of the impaired renal vascular responses to Ang II. The insulin-resistant state due to fructose feeding has 


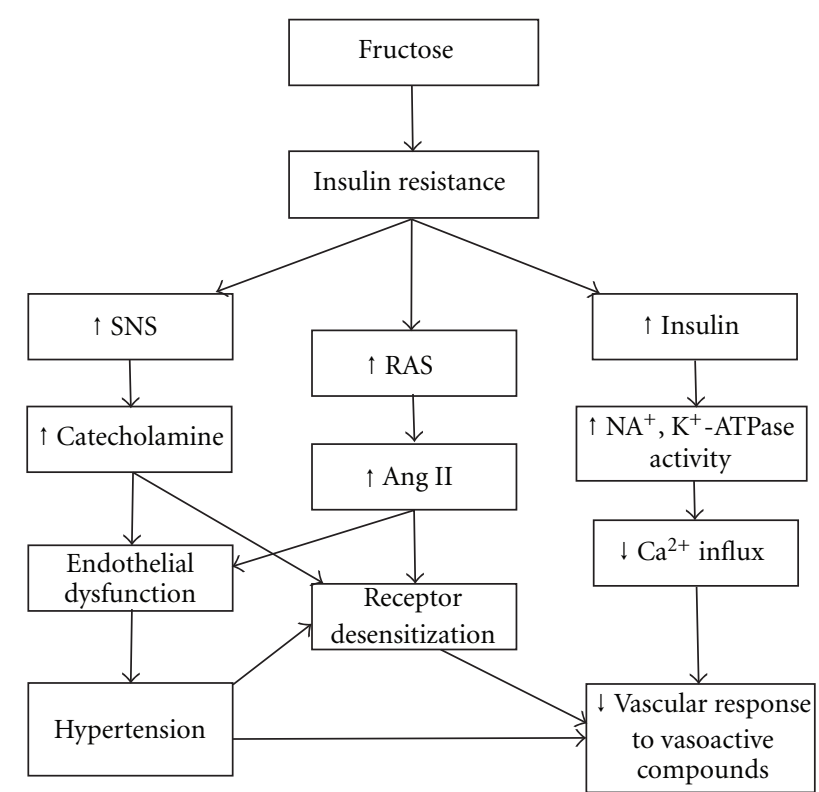

Figure 3: Proposed mechanisms that may explain the decreased vascular responses to vasoactive compounds in the fructose-fed rats. $\uparrow$ and $\downarrow$ stand for increase and decrease, respectively.

also been associated with enhanced contractile responses to Ang II with AT1 receptor upregulation and increased endothelial $\mathrm{O}_{2}{ }^{-}$production caused by an activation of $\mathrm{NAD}(\mathrm{P}) \mathrm{H}$ oxidase [127]. Interestingly, treatment with an AT1 receptor blocker resulted in an inhibition of $\mathrm{NAD}(\mathrm{P}) \mathrm{H}$ oxidase and the Ang II-induced vasoconstriction, in addition to amelioration of endothelial dysfunction in this fructosefed model.

The data regarding the effect of fructose-feeding on the functional contribution of $\alpha_{1}$-adrenoceptors subtypes in the renal vasculature is scarce. The only available reports are those arising from our own laboratory which have demonstrated that $\alpha_{1 \mathrm{~B}}$-adrenoceptors make a lower contribution to renal vascular tone in fructose-fed rats [16]. This may provide further support for the notion that $\alpha_{1 A^{-}}$and/or $\alpha_{1 \mathrm{D}}$-adrenoceptors are major contributors in mediating the renal vasoconstriction induced by adrenergic stimuli in rats during hypertension. From the available reports, it is clear that the effects of fructose-feeding on the vascular response to adrenergic activation are not well investigated and need further exploration. Figure 3 presents some of the proposed mechanisms that may explain the decreased vascular responses to vasoactive compounds in fructose-fed rats.

\section{Fructose Consumption and the Sympathetic Nervous System}

Insulin has been acknowledged as playing key roles in a variety of important biological functions, one of which is an activation of the sympathetic nervous system. This sympatho-excitatory effect of insulin may be mediated by a baroreflex mechanism [158] or by a direct effect of insulin on noradrenaline release from sympathetic nerve endings $[159,160]$. These effects may possibly explain the link between hyperinsulinemia and high blood pressure [159]. As insulin activates the sympathetic nervous system, there will be an increased peripheral vascular tone which in turn will elevate blood pressure. In support of this concept, insulin infusion was found to elevate plasma noradrenaline and blood pressure levels in normal individuals [161] and to increase cardiac sympathetic activity in type 2 diabetic patients [162]. Moreover, in obese subjects, the correction of hyperinsulinemia decreased both circulating noradrenaline levels and blood pressure [163]. This relationship received direct support from the observation in normal humans that hyperinsulinemia increased noradrenaline release from forearm muscle which was more pronounced in patients with essential hypertension [164].

The exact function of insulin and its receptors within the central nervous system (CNS) has been uncertain until recently. In addition to its regulatory effect on energy storage, insulin plays a key modulatory role in afferent (and efferent) hypothalamic pathways governing energy intake [165]. It has been shown that antagonism of insulin signaling in the brain can impair the ability of circulating insulin to inhibit glucose production [166]. On the other hand, there is evidence that increased sympathetic activity results in insulin resistance due to $\alpha_{1}$-adrenoceptor activation causing a reduction in blood flow and therefore a reduction in glucose delivery to skeletal muscle $[100,159]$. The outcome, then, is a continuous stimulation of sympathetic nervous system due to compensatory hyperinsulinemia in response to the insulin resistance. This view has been supported by studies demonstrating that blockade of the sympathetic nervous system, by chemical sympathectomy [72] or decreasing sympathetic outflow [73, 111], prevented both the development of hyperinsulinemia and hypertension in fructose-fed rats (Table 2). This would imply that the development of hyperinsulinemia and high blood pressure in this model depends on an intact sympathetic nervous system [72]. These findings, together with points discussed earlier in this paper, are in agreement regarding the key role played by this system in the metabolic syndrome.

\section{Effect of Fructose Feeding on Baroreflex Control of the Sympathetic Nervous System}

It becomes evident now that the metabolic syndrome is associated with higher sympathetic nerve activity which is modulated by insulin resistance as well as alterations in reflex regulatory mechanisms [167]. The baroreflex control of arterial blood pressure is considered key to cardiovascular homeostasis but there is controversy regarding its long-term control of sympathetic activity and arterial pressure. There is a consensus that the baroreflex mechanism is important in the short-term regulation of heart rate, sympathetic tone, and consequently blood pressure. However, it is becoming recognised that pressure-induced increases in baroreflex activity persist for longer periods of time than previously reported. Impairment of baroreflex sensitivity in the 
metabolic syndrome involves both the sympatho-inhibitory and the sympatho-excitatory baroreflex components [168] as well as impairment of the cardiopulmonary mechano- and chemo-receptors [169]. Baroreflex sensitivity derived from measuring blood pressure has been utilized as a parameter to assess cardiovascular autonomic balance which is altered in hypertension [170-172]. In addition to cardiovascular disease, impaired baroreflex sensitivity is associated with the metabolic syndrome. In individuals with insulin resistance, the baroreflex sensitivity was found to be significantly lower compared to their healthy counterparts [173] with hypertension. It appeared that obesity and hypertriglyceridemia may be the main contributory factors associated with the impaired baroreflex sensitivity during metabolic syndrome [174]. Moreover, Ziegler and others have reported abnormalities of baroreflex sensitivity in relation to the cardiovascular system in diabetes mellitus in humans $[175,176]$ and rats $[177,178]$. Impairment in baroreflex sensitivity has also been reported in streptozotocin-induced diabetic rats fed on highfat emulsion for 30 days [179]. There has been a suggestion that the higher circulating levels of vasopressin and Ang II in diabetic humans and rats play a role in this altered baroreflex function $[180,181]$. However, inhibition of the renin-angiotensin system with the angiotensin converting enzyme inhibitor, enalapril, was not associated with any alteration in baroreflex-mediated renal sympatho-inhibition in diabetic rats [182]. A further suggestion has been that lipid abnormalities which arise in the metabolic syndrome are associated with impaired baroreflex sensitivity. Therefore, diets known to improve the lipid profile, such as a diet high in monounsaturated fatty acids, have been found to improve baroreflex sensitivity in subjects with metabolic syndrome. This provides evidence that the baroreflex mechanism is particularly sensitive and influenced by changes in diet-fat intake [183]. Ai et al. [179] have shown that the high pressure baroreflex sensitivity is impaired in Wistar rats fed a highfat and carbohydrate diet in which fructose and sucrose are included as a diet component. However, a study by Wong and Johns [18] reported an impairment in the reflex efferent renal sympatho-inhibition to volume expansion in the diet-induced obese rats but not in the fructose-fed rats. This may possibly be attributed to the different sympathetic mechanisms and abnormalities responsible for the development of high blood pressure in fructose-fed rat compared to diet-induced obese rat. Other studies have also reported an attenuation of the baroreflex compensatory mechanism in insulin-resistant Zucker obese rats [157]. Based on the notion that sympathetic hyperactivity is present in the fructose-rich diet model of insulin resistance, inhibition of the sympathetic nervous system would be a significant target for drug treatment (Table 2).

\section{Fructose Consumption and Renal Sodium Handling}

A possible mechanism by which hyperinsulinemia could lead to hypertension is excessive sodium retention due to increased renal tubular sodium reabsorption [184]. During insulin resistance, the vasodilator effect of insulin may be blunted and hence becomes unable to offset the counterregulatory fall in proximal tubular sodium reabsorption during hyperinsulinemia and thus predispose to sodium retention [185]. Furthermore, acute administration of insulin results in decreased excretion of sodium in animals [186, 187] and humans [184, 188]. It has been reported that insulin-induced hypertension is associated with a shift in pressure natriuresis with the impairment in renal sodium excretion and seems to occur chronically during insulin infusion [96, 189, 190]. Albeit that studies have shown the reduction in sodium excretion after the long-term consumption of fructose-rich diet $[81,191]$, other studies have reported no change in sodium excretion $[76,156]$ (Table 3). Interestingly, Iyer and Katovich [192] have shown that fructose feeding for 6 weeks does not cause any change in sodium excretion, and they have suggested that sodium retention may not be the cause of high blood pressure in this model. At an intrarenal level, urinary sodium excretion and renal interstitial hydrostatic pressure have been suggested to be under the influence of the NO system [193, 194], and any defect in NO generation may result in salt-sensitive hypertension [195-197]. Thus, the issue arises as whether there is the development of salt-sensitive hypertension in an insulin-resistant state when there is impairment of the renal NO system. In addition, eNOS has been reported to play an important role in sodium handling [198] and has been demonstrated to be decreased in the kidneys of fructose-fed and salt-sensitive fructose-fed hypertensive rats [108, 126]. As yet, the mechanism by which fructose-feeding results in raised sodium reabsorption which may contribute to the initiation of hypertension remains to be determined.

\section{Fructose Consumption and Progression of Renal Disease}

There is controversy regarding the causal relationship between fructose-feeding and the incidence of chronic kidney disease. However, several studies have reported that fruc-tose intake is associated with hyperuricaemia $[63,200,205,206]$, albuminuria [199, 200, 207], and progression into kidney disease [207]. Others have shown that fructose feeding for 2 weeks resulted in hyperfiltration and hyperplasia of mesangial cells in glomeruli [204]. Sánchez-Lozada et al. [11] reported that high fructose intake in addition to inducing the metabolic syndrome can result in the development of kidney hypertrophy, glomerular hypertension, cortical vasoconstriction, and arteriolopathy. Moreover, fructose consumption was found to accelerate the progression of chronic renal disease in rats [22] and has been reported to induce glomerular hypertension and sclerosis of the afferent arteriole [11]. Cirillo et al. [208] have interestingly shown that postprandial concentrations of fructose activate inflammatory mediators in proximal tubular cells in humans. In addition, functional changes including elevated plasma creatinine and albuminuria and morphological changes including fatty infiltration and thickening of glomeruli have 
TABLE 3: The effect of fructose feeding on kidney morphology, function, and haemodynamics in rat.

\begin{tabular}{|c|c|c|c|}
\hline Amount fed & $\begin{array}{l}\text { Length of } \\
\text { study }\end{array}$ & Effect & Reference \\
\hline \multirow[t]{9}{*}{$60 \%$ fructose in diet } & 4 weeks & $\leftrightarrow$ Urine volume, $\leftrightarrow$ sodium excretion, $\leftrightarrow$ creatinin clearance & {$[76]$} \\
\hline & 4 weeks & $\leftrightarrow$ Urine volume, $\downarrow$ sodium excretion, $\leftrightarrow \mathrm{RBF}, \leftrightarrow \mathrm{CBF}, \downarrow \mathrm{MBF}$ & {$[81]$} \\
\hline & 6 month & $\leftrightarrow$ Serum creatinine, $\leftrightarrow$ BUN & {$[47]$} \\
\hline & 8 weeks & $\begin{array}{l}\text { Kidney hypertrophy, glomerular hypertension, cortical } \\
\text { vasoconstriction, arteriolopathy }\end{array}$ & {$[11]$} \\
\hline & 12 months & Glomerular sclerosis, albuminurea, $\uparrow$ kidney weight & [199] \\
\hline & 60 days & $\begin{array}{l}\uparrow \text { Plasma and urine urea level, } \uparrow \text { plasma and urine uric acid, } \\
\uparrow \text { plasma and urine creatinine, } \uparrow \text { plasma and urine albumin and } \\
\text { total protein, fatty infiltration, thickening of glomeruli }\end{array}$ & {$[200]$} \\
\hline & 30 days & $\uparrow$ Plasma sodium, $\downarrow$ sodium excretion, $\uparrow$ urine volume & {$[191]$} \\
\hline & 8 weeks & $\begin{array}{l}\leftrightarrow \mathrm{GFR} ; \leftrightarrow \text { afferent arteriole resistance; } \leftrightarrow \text { efferent arteriole } \\
\text { resistance glomerular hypertension, cortical vasoconstriction, } \\
\text { arteriolopathy }\end{array}$ & {$[67]$} \\
\hline & 6 weeks & Kidney hypertrophy, tubular proliferation, and focal injury & {$[201]$} \\
\hline \multirow[t]{2}{*}{$66 \%$ fructose in diet } & 6 weeks & $\leftrightarrow$ Urine volume, $\leftrightarrow$ sodium excretion & {$[192]$} \\
\hline & 8 weeks & $\leftrightarrow$ Kidney weight, $\leftrightarrow$ RBF, $\leftrightarrow$ urine volume, $\leftrightarrow$ sodium excretion & {$[156]$} \\
\hline $65 \%$ fructose in diet & 4 weeks & $\uparrow$ Kidney weight, swollen proximal tubular cells & {$[202]$} \\
\hline $57 \%$ fructose in diet & 10 weeks & $\leftrightarrow$ Plasma creatinine, $\uparrow$ kidney weight & {$[36]$} \\
\hline $\begin{array}{l}10 \% \text { fructose in } \\
\text { drinking water }\end{array}$ & 8 weeks & $\begin{array}{l}\text { Kidney hypertrophy, glomerular hypertension, cortical } \\
\text { vasoconstriction, and arteriolopathy }\end{array}$ & {$[11]$} \\
\hline $20 \%$ fructose in diet & 9 weeks & $\uparrow$ Kidney weight & {$[203]$} \\
\hline $25 \%$ fructose in diet & 2 weeks & $\begin{array}{l}\uparrow \text { Creatinine clearance, hyperfiltration, mesangial cells } \\
\text { proliferation }\end{array}$ & {$[204]$} \\
\hline $\begin{array}{l}20 \% \text { fructose in } \\
\text { drinking water }\end{array}$ & 8 weeks & $\leftrightarrow$ Kidney weight, $\leftrightarrow \mathrm{CBF}, \leftrightarrow \mathrm{RAP}$ & {$[16]$} \\
\hline
\end{tabular}

RBF: Renal Blood Flow, CBF: Cortical Blood Flow, MBF: Medullary Blood Flow, BUN: Blood Urea Nitrogen, GFR: Glomerular Filtration Rate, RAP: Renal Arterial Pressure. $\uparrow, \downarrow$ and $\leftrightarrow$ indicate increase, decrease, and no effect, respectively.

been reported after 60 days of fructose feeding in rat [200]. The renal injury due to fructose-feeding was suggested to be involved in the increased blood pressure in this model [22]. On the other hand, altered cardiovascular homeostasis accompanying kidney damage may also contribute to the development of hypertension. It has been reported that renal disturbances associated with fructose-induced metabolic syndrome become more apparent when higher concentrations of fructose are used [11].

It becomes apparent from these reports that the deterioration in renal haemodynamics and morphology depends on the prevalence of metabolic syndrome features which, as indicated earlier, are directly proportional to the amount of fructose ingested. This view is reinforced by the observations that consumption of $60 \%$ fructose in the diet produces larger increases in blood pressure, plasma uric acid, and triglycerides than $10 \%$ of fructose in drinking water [11]. Furthermore, the presence of hyperinsulinemia due to fructose feeding may also play a role in the progression of renal disease. This view is supported by the observations that treatment of fructose-fed rats with troglitazone to correct hyperinsulinemia slowed the progression of renal disease [209]. Roysommuti et al. [210] have proposed the hypothesis that a long-term high carbohydrate diet produces impairment of renal function which is dependent on an intact renin-angiotensin system. It has been suggested that the increased urinary NO excretion in high fructose-fed rats gives an indication of its role in the pathogenesis of the early renal changes induced by fructose intake [211]. Interestingly, this study showed that in addition to higher urinary excretion of NO, the one-month fructose-fed rats had glomerular hypertrophy and increased expression of inducible nitric oxide synthase enzyme (iNOS) isoform in the kidney. The role of NO is reinforced by the observation that L-NAME, a nitric oxide synthase (NOS) enzyme inhibitor, can attenuate these renal changes [211]. Although hyperinsulinemia has been suggested as a contributing factor to the pathogenesis of renal disease in this model, to date the exact mechanisms responsible for the morphological and functional changes in the kidney of fructose-fed rat have not been identified. Table 3 shows the effect of various routes, amounts, and lengths of fructose intake on the morphology, function, and haemodynamics in the kidney of rat.

\section{Conclusions}

Dietary fructose intake produces hypertension, dyslipidemia, insulin resistance and hyperinsulinemia. In addition, consumption of a high-fructose diet during hypertension increases mortality and left ventricular wall thickness 
compared to either a high fat, high starch, or a "Western" diet [212]. Insulin resistance and hyperinsulinemia may be responsible for endothelial dysfunction and thereby participate in the elevated blood pressure in this model. Most importantly, over activity of the sympathetic nervous system due to fructose-feeding has been linked to insulin resistance and may contribute to the onset and maintenance of cardiovascular and renal complications. The intake of increasing amount of fructose is associated with various manifestations of metabolic syndrome that consequently lead to derangement of renal morphology and haemodynamics. Thus, it is evident that adverse effects resulting from fructose ingestion are concentration and time dependent. Moreover, hyperinsulinemia and hypertension contribute significantly to the progressive deterioration in renal function associated with the metabolic syndrome. Different interventions have been utilized to correct the abnormalities associated with fructoseinduced metabolic syndrome. The use of antioxidants, blood pressure lowering agents, and other interventions capable of enhancing insulin sensitivity were found to have beneficial effects in this model. There is an enigma as to whether fructose-feeding enhances or decreases or is without effect on vascular contractile responses. Data to date indicate that fructose-feeding results in blunted renal vascular response to adrenergic agonists and Ang II associated with higher circulating levels of noradrenaline and Ang II. Furthermore, there is a scarcity of studies on the impact of fructose-feeding on baroreflex control mechanisms and the role played by the renal sympathetic nerves in regulating kidney function in this model.

\section{References}

[1] G. M. Reaven, "Role of insulin resistance in human disease," Diabetes, vol. 37, no. 12, pp. 1595-1607, 1988.

[2] B. L. Wajchenberg, D. A. Malerbi, M. S. Rocha, A. C. Lerario, and A. T. Santomauro, "Syndrome X: a syndrome of insulin resistance. Epidemiological and clinical evidence," Diabetes/Metabolism Reviews, vol. 10, no. 1, pp. 19-29, 1994.

[3] R. L. Hanson, G. Imperatore, P. H. Bennett, and W. C. Knowler, "Components of the "metabolic syndrome" and incidence of type 2 diabetes," Diabetes, vol. 51, no. 10, pp. 3120-3127, 2002.

[4] C. Lorenzo, M. Okoloise, K. Williams, M. P. Stern, and S. M. Haffner, "The metabolic syndrome as predictor of type 2 diabetes: the san antonio heart study," Diabetes Care, vol. 26, no. 11, pp. 3153-3159, 2003.

[5] B. Isomaa, P. Almgren, T. Tuomi et al., "Cardiovascular morbidity and mortality associated with the metabolic syndrome," Diabetes Care, vol. 24, no. 4, pp. 683-689, 2001.

[6] H. M. Lakka, D. E. Laaksonen, T. A. Lakka et al., "The metabolic syndrome and total and cardiovascular disease mortality in middle-aged men," Journal of the American Medical Association, vol. 288, no. 21, pp. 2709-2716, 2002.

[7] S. Malik, N. D. Wong, S. S. Franklin et al., "Impact of the metabolic syndrome on mortality from coronary heart disease, cardiovascular disease, and all causes in United States adults," Circulation, vol. 110, no. 110, pp. 1245-1250, 2004.

[8] I. S. Hwang, W. C. Huang, J. N. Wu, L. R. Shian, and G. M. Reaven, "Effect of fructose-induced hypertension on the renin-angiotensin-aldosterone system and atrial natriuretic factor," American Journal of Hypertension, vol. 2, no. 6, pp. 424-427, 1989.

[9] A. W. Miller, P. V. G. Katakam, and M. R. Ujhelyi, "Impaired endothelium-mediated relaxation in coronary arteries from insulin-resistant rats," Journal of Vascular Research, vol. 36, no. 5, pp. 385-392, 1999.

[10] Y. Rayssiguier, E. Gueux, W. Nowacki, E. Rock, and A. Mazur, "High fructose consumption combined with low dietary magnesium intake may increase the incidence of the metabolic syndrome by inducing inflammation," Magnesium Research, vol. 19, no. 4, pp. 237-243, 2006.

[11] L. G. Sánchez-Lozada, E. Tapia, A. Jiménez et al., "Fructoseinduced metabolic syndrome is associated with glomerular hypertension and renal microvascular damage in rats," American Journal of Physiology, vol. 292, no. 1, pp. F423F429, 2007.

[12] S. Dai and J. H. McNeill, "Fructose-induced hypertension in rats is concentration- and duration-dependent," Journal of Pharmacological and Toxicological Methods, vol. 33, no. 2, pp. 101-107, 1995.

[13] Y. H. Dan, K. M. Boini, B. Friedrich et al., "Blunted hypertensive effect of combined fructose and high-salt diet in genetargeted mice lacking functional serum- and glucocorticoidinducible kinase SGK1," American Journal of Physiology, vol. 290, no. 4, pp. R935-R944, 2006.

[14] X. Xu, C. X. Zhao, L. Wang et al., "Increased CYP2J3 expression reduces insulin resistance in fructose-treated rats and db/db mice," Diabetes, vol. 59, no. 4, pp. 997-1005, 2010.

[15] H. Bar-On and Y. Stein, "Effect of glucose and fructose administration on lipid metabolism in the rat," Journal of Nutrition, vol. 94, no. 1, pp. 95-105, 1968.

[16] M. H. Abdulla, M. A. Sattar, N. A. Abdullah, M. A. H. Khan, K. R. L. Anand Swarup, and E. J. Johns, "The contribution of $\alpha(1 \mathrm{~B})$-adrenoceptor subtype in the renal vasculature of fructose-fed Sprague-Dawley rats," European Journal of Nutrition, vol. 50, no. 4, pp. 251-260, 2011.

[17] C. S. Motoyama, M. J. Pinto, F. S. Lira, E. B. Ribeiro, C. M. Do Nascimento, and L. M. Oyama, "Gum Guar fiber associated with fructose reduces serum triacylglycerol but did not improve the glucose tolerance in rats," Diabetology and Metabolic Syndrome, vol. 2, article 61, 2010.

[18] P. S. K. Wong and E. J. Johns, "Effect of acute saline volume loading on renal sympathetic nerve activity in anaesthetised fructose-fed and fat-fed rats," Journal of the Autonomic Nervous System, vol. 75, no. 1, pp. 60-69, 1999.

[19] C. M. Barros, R. Q. Lessa, M. P. Grechi et al., "Substitution of drinking water by fructose solution induces hyperinsulinemia and hyperglycemia in hamsters," Clinics, vol. 62, no. 3, pp. 327-334, 2007.

[20] M. Félétou, M. Boulanger, J. Staczek, O. Broux, and J. Duhault, "Fructose diet and VEGF-induced plasma extravasation in hamster cheek pouch," Acta Pharmacologica Sinica, vol. 24, no. 3, pp. 207-211, 2003.

[21] V. Farah, K. M. Elased, Y. Chen et al., "Nocturnal hypertension in mice consuming a high fructose diet," Autonomic Neuroscience, vol. 130, no. 1-2, pp. 41-50, 2006.

[22] M. S. Gersch, W. Mu, P. Cirillo et al., "Fructose, but not dextrose, accelerates the progression of chronic kidney disease," American Journal of Physiology, vol. 293, no. 4, pp. F1256F1261, 2007.

[23] J. E. Jordan, S. A. Simandle, C. D. Tulbert, D. W. Busija, and A. W. Miller, "Fructose-fed rats are protected against ischemia/reperfusion injury," Journal of Pharmacology and 
Experimental Therapeutics, vol. 307, no. 3, pp. 1007-1011, 2003.

[24] I. S. Hwang, H. Ho, B. B. Hoffman, and G. M. Reaven, "Fructose-induced insulin resistance and hypertension in rats," Hypertension, vol. 10, no. 5, pp. 512-516, 1987.

[25] C. Taghibiglou, A. Carpentier, S. C. Van Iderstine et al., "Mechanisms of hepatic very low density lipoprotein overproduction in insulin resistance. Evidence for enhanced lipoprotein assembly, reduced intracellular ApoB degradation, and increased microsomal triglyceride transfer protein in a fructose-fed hamster model," Journal of Biological Chemistry, vol. 275, no. 12, pp. 8416-8425, 2000.

[26] F. J. Martinez, R. A. Rizza, and J. C. Romero, "Highfructose feeding elicits insulin resistance, hyperinsulinism, and hypertension in normal mongrel dogs," Hypertension, vol. 23, no. 4, pp. 456-463, 1994.

[27] J. Hallfrisch, K. C. Ellwood, and O. E. Michaelis IV, "Effects of dietary fructose on plasma glucose and hormone responses in normal and hyperinsulinemic men," Journal of Nutrition, vol. 113, no. 9, pp. 1819-1826, 1983.

[28] S. Reiser, A. S. Powell, D. J. Scholfield, P. Panda, M. Fields, and J. J. Canary, "Day-long glucose, insulin, and fructose responses of hyperinsulinemic and nonhyperinsulinemic men adapted to diets containing either fructose or high-amylose cornstarch," American Journal of Clinical Nutrition, vol. 50, no. 5, pp. 1008-1014, 1989.

[29] R. M. N. Bezerra, M. Ueno, M. S. Silva, D. Q. Tavares, C. R. O. Carvalho, and M. J. A. Saad, "A high fructose diet affects the early steps of insulin action in muscle and liver of rats," Journal of Nutrition, vol. 130, no. 6, pp. 1531-1535, 2000.

[30] N. Togashi, N. Ura, K. Higashiura, H. Murakami, and K. Shimamoto, "Effect of TNF- $\alpha$-converting enzyme inhibitor on insulin resistance in fructose-fed rats," Hypertension, vol. 39, no. 2, pp. 578-580, 2002.

[31] L. B. Lingelbach and R. B. McDonald, "Description of the long-term lipogenic effects of dietary carbohydrates in male Fischer 344 rats," Journal of Nutrition, vol. 130, no. 12, pp. 3077-3084, 2000.

[32] G. D’Angelo, A. A. Elmarakby, D. M. Pollock, and D. W. Stepp, "Fructose feeding increases insulin resistance but not blood pressure in Sprague-Dawley rats," Hypertension, vol. 46, no. 4, pp. 806-811, 2005.

[33] S. N. Iyer and M. J. Katovich, "Effect of chronic losartan potassium treatment on fructose-induced hypertension," Life Sciences, vol. 55, no. 7, pp. PL139-PL144, 1994.

[34] C. Catena, G. Giacchetti, M. Novello, G. Colussi, A. Cavarape, and L. A. Sechi, "Cellular mechanisms of insulin resistance in rats with fructose-induced hypertension," American Journal of Hypertension, vol. 16, no. 11, pp. 973-978, 2003.

[35] R. B. Kanarek and N. Orthen Gambill, "Differential effects of sucrose, fructose and glucose on carbohydrate-induced obesity in rats," Journal of Nutrition, vol. 112, no. 8, pp. 15461554, 1982.

[36] S. W. Rizkalla, J. Boillot, V. Tricottet et al., "Effects of chronic dietary fructose with and without copper supplementation on glycaemic control, adiposity, insulin binding to adipocytes and glomerular basement membrane thickness in normal rats," British Journal of Nutrition, vol. 70, no. 1, pp. 199-209, 1993.

[37] S. E. Kasim-Karakas, H. Vriend, R. Almario, L. C. Chow, and M. N. Goodman, "Effects of dietary carbohydrates on glucose and lipid metabolism in golden Syrian hamsters," Journal of
Laboratory and Clinical Medicine, vol. 128, no. 2, pp. 208213, 1996.

[38] M. G. Tordoff and A. M. Alleva, "Effect of drinking soda sweetened with aspartame or high-fructose corn syrup on food intake and body weight," American Journal of Clinical Nutrition, vol. 51, no. 6, pp. 963-969, 1990.

[39] J. W. Anderson, L. J. Story, N. C. Zettwoch, N. J. Gustafson, and B. S. Jefferson, "Metabolic effects of fructose supplementation in diabetic individuals," Diabetes Care, vol. 12, no. 5, pp. 337-344, 1989.

[40] M. Huynh, J. J. Luiken, W. Coumans, and R. C. Bell, "Dietary fructose during the suckling period increases body weight and fatty acid uptake into skeletal muscle in adult rats," Obesity, vol. 16, no. 8, pp. 1755-1762, 2008.

[41] K. L. Teff, S. S. Elliott, M. Tschöp et al., "Dietary fructose reduces circulating insulin and leptin, attenuates postprandial suppression of ghrelin, and increases triglycerides in women," Journal of Clinical Endocrinology and Metabolism, vol. 89, no. 6, pp. 2963-2972, 2004.

[42] N. Roglans, L. Vilà, M. Farré et al., "Impairment of hepatic STAT-3 activation and reduction of PPAR $\alpha$ activity in fructose-fed rats," Hepatology, vol. 45, no. 3, pp. 778-788, 2007.

[43] Y. C. Lee, Y. H. Ko, Y. P. Hsu, and L. T. Ho, "Plasma leptin response to oral glucose tolerance and fasting/re-feeding tests in rats with fructose-induced metabolic derangements," Life Sciences, vol. 78, no. 11, pp. 1155-1162, 2006.

[44] B. W. Huang, M. T. Chiang, H. T. Yao, and W. Chiang, "The effect of high-fat and high-fructose diets on glucose tolerance and plasma lipid and leptin levels in rats," Diabetes, Obesity and Metabolism, vol. 6, no. 2, pp. 120-126, 2004.

[45] A. D. Mooradian, J. Chehade, R. Hurd, and M. J. Haas, "Monosaccharide-enriched diets cause hyperleptinemia without hypophagia," Nutrition, vol. 16, no. 6, pp. 439$441,2000$.

[46] K. A. Lê, D. Faeh, R. Stettler et al., "A 4-wk high-fructose diet alters lipid metabolism without affecting insulin sensitivity or ectopic lipids in healthy humans," American Journal of Clinical Nutrition, vol. 84, no. 6, pp. 1374-1379, 2006.

[47] A. Shapiro, W. Mu, C. Roncal, K. Y. Cheng, R. J. Johnson, and P. J. Scarpace, "Fructose-induced leptin resistance exacerbates weight gain in response to subsequent high-fat feeding," American Journal of Physiology, vol. 295, no. 5, pp. R1370R1375, 2008.

[48] P. J. Scarpace and Y. Zhang, "Elevated leptin: consequence or cause of obesity?" Frontiers in Bioscience, vol. 12, pp. 35313544, 2007.

[49] M. E. Bizeau and M. J. Pagliassotti, "Hepatic adaptations to sucrose and fructose," Metabolism, vol. 54, no. 9, pp. 11891201, 2005.

[50] P. J. Havel, "Dietary fructose: implications for dysregulation of energy homeostasis and lipid/carbohydrate metabolism," Nutrition Reviews, vol. 63, no. 5, pp. 133-137, 2005.

[51] A. D. Baron, "Insulin and the vasculature-old actors, new roles," Journal of Investigative Medicine, vol. 44, no. 8, pp. 406-412, 1996.

[52] A. D. Baron and M. G. Clark, "Role of blood flow in the regulation of muscle glucose uptake," Annual Review of Nutrition, vol. 17, pp. 487-499, 1997.

[53] G. M. Reaven, "Insulin resistance/compensatory hyperinsulinemia, essential hypertension, and cardiovascular disease," Journal of Clinical Endocrinology and Metabolism, vol. 88, no. 6, pp. 2399-2403, 2003. 
[54] A. W. Thorburn, L. H. Storlien, A. B. Jenkins, S. Khouri, and E. W. Kraegen, "Fructose-induced in vivo insulin resistance and elevated plasma triglyceride levels in rats," American Journal of Clinical Nutrition, vol. 49, no. 6, pp. 1155-1163, 1989.

[55] J. Hallfrisch, F. Lazar, C. Jorgensen, and S. Reiser, "Insulin and glucose responses in rats fed sucrose or starch," American Journal of Clinical Nutrition, vol. 32, no. 4, pp. 787-793, 1979.

[56] I. Zavaroni, S. Sander, S. Scott, and G. M. Reaven, "Effect of fructose feeding on insulin secretion and insulin action in the rat," Metabolism, vol. 29, no. 10, pp. 970-973, 1980.

[57] K. Higashiura, N. Ura, T. Takada et al., "The effects of an angiotensin-converting enzyme inhibitor and an angiotensin II receptor antagonist on insulin resistance in fructose-fed rats," American Journal of Hypertension, vol. 13, no. 3, pp. 290-297, 2000.

[58] R. A. DeFronzo, "Insulin resistance, hyperinsulinemia, and coronary artery disease: a complex metabolic web," Journal of Cardiovascular Pharmacology, vol. 20, supplement 11, pp. S1-S16, 1992.

[59] S. Bhanot and J. H. McNeill, "Insulin and hypertension: a causal relationship?" Cardiovascular Research, vol. 31, no. 2, pp. 212-221, 1996.

[60] Y. Wei, D. Wang, F. Topczewski, and M. J. Pagliassotti, "Fructose-mediated stress signaling in the liver: implications for hepatic insulin resistance," Journal of Nutritional Biochemistry, vol. 18, no. 1, pp. 1-9, 2007.

[61] C. Catena, A. Cavarape, M. Novello, G. Giacchetti, and L. A. Sechi, "Insulin receptors and renal sodium handling in hypertensive fructose-fed rats," Kidney International, vol. 64, no. 6, pp. 2163-2171, 2003.

[62] T. Nakagawa, H. Hu, S. Zharikov et al., "A causal role for uric acid in fructose-induced metabolic syndrome," American Journal of Physiology, vol. 290, no. 3, pp. F625-F631, 2006.

[63] J. Perheentupa and K. Raivio, "Fructose-induced hyperuricaemia," Lancet, vol. 2, no. 7515, pp. 528-531, 1967.

[64] P. H. Mäenpää, K. O. Raivio, and M. P. Kekomäki, "Liver adenine nucleotides: fructose-induced depletion and its effect on protein synthesis," Science, vol. 161, no. 3847, pp. 1253-1254, 1968.

[65] S. Reungjui, C. A. Roncal, W. Mu et al., "Thiazide diuretics exacerbate fructose-induced metabolic syndrome," Journal of the American Society of Nephrology, vol. 18, no. 10, pp. 27242731, 2007.

[66] G. Mercuro, C. Vitale, E. Cerquetani et al., "Effect of hyperuricemia upon endothelial function in patients at increased cardiovascular risk," American Journal of Cardiology, vol. 94, no. 7, pp. 932-935, 2004.

[67] L. G. Sánchez-Lozada, E. Tapia, P. Bautista-García et al., "Effects of febuxostat on metabolic and renal alterations in rats with fructose-induced metabolic syndrome," American Journal of Physiology, vol. 294, no. 4, pp. F710-F718, 2008.

[68] G. M. Reaven, H. Ho, and B. B. Hoffman, "Attenuation of fructose-induced hypertension in rats by exercise training," Hypertension, vol. 12, no. 2, pp. 129-132, 1988.

[69] G. M. Reaven, H. Ho, and B. B. Hoffmann, "Somatostatin inhibition of fructose-induced hypertension," Hypertension, vol. 14, no. 2, pp. 117-120, 1989.

[70] S. Bhanot, J. H. McNeill, and M. Bryer-Ash, "Vanadyl sulfate prevents fructose-induced hyperinsulinemia and hypertension in rats," Hypertension, vol. 23, no. 3, pp. 308-312, 1994.

[71] T. A. Kotchen, S. Reddy, and H. Y. Zhang, "Increasing insulin sensitivity lowers blood pressure in the fructose-fed rat,"
American Journal of Hypertension, vol. 10, no. 9, pp. 10201026, 1997.

[72] S. Verma, S. Bhanot, and J. H. McNeill, "Sympathectomy prevents fructose-induced hyperinsulinemia and hypertension," European Journal of Pharmacology, vol. 373, no. 2-3, pp. R1R4, 1999.

[73] L. Pénicaud, M. F. Berthault, J. Morin, M. Dubar, A. Ktorza, and P. Ferre, "Rilmenidine normalizes fructoseinduced insulin resistance and hypertension in rats," Journal of Hypertension, Supplement, vol. 16, no. 3, pp. S45-S49, 1998.

[74] Y. Erlich and T. Rosenthal, "Contribution of nitric oxide to the beneficial effects of enalapril in the fructose-induced hyperinsulinemic rat," Hypertension, vol. 28, no. 5, pp. 754757, 1996.

[75] Y. Kamari, A. Harari, A. Shaish et al., "Effect of telmisartan, angiotensin II receptor antagonist, on metabolic profile in fructose-induced hypertensive, hyperinsulinemic, hyperlipidemic rats," Hypertension Research, vol. 31, no. 1, pp. 135140, 2008.

[76] J. Navarro-Cid, R. Maeso, F. Perez-Vizcaino et al., "Effects of losartan on blood pressure, metabolic alterations, and vascular reactivity in the fructose-induced hypertensive rat," Hypertension, vol. 26, no. 6, pp. 1074-1078, 1995.

[77] F. Huang, M. A. R. Lezama, J. A. P. Ontiveros et al., "Effect of losartan on vascular function in fructose-fed rats: the role of perivascular adipose tissue," Clinical and Experimental Hypertension, vol. 32, no. 2, pp. 98-104, 2010.

[78] T. Uchida, K. Okumura, T. Ito et al., "Quinapril treatment restores the vasodilator action of insulin in fructosehypertensive rats," Clinical and Experimental Pharmacology and Physiology, vol. 29, no. 5-6, pp. 381-385, 2002.

[79] M. Takada, N. Ura, K. Higashiura, H. Murakami, N. Togashi, and K. Shimamoto, "Effects of cilnidipine on muscle fiber composition, capillary density and muscle blood flow in fructose-fed rats," Hypertension Research, vol. 24, no. 5, pp. 565-572, 2001.

[80] H. W. Tan, S. S. Xing, X. P. Bi et al., "Felodipine attenuates vascular inflammation in a fructose-induced rat model of metabolic syndrome via the inhibition of NF- $\kappa \mathrm{B}$ activation," Acta Pharmacologica Sinica, vol. 29, no. 9, pp. 1051-1059, 2008.

[81] S. Onuma and K. Nakanishi, "Superoxide dismustase mimetic tempol decreases blood pressure by increasing renal medullary blood flow in hyperinsulinemic-hypertensive rats," Metabolism, vol. 53, no. 10, pp. 1305-1308, 2004.

[82] B. Unger and B. Patil, "Apocynin improves endothelial function and prevents the development of hypertension in fructose fed rat," Indian Journal of Pharmacology, vol. 41, no. 5, pp. 208-212, 2009.

[83] A. Cosenzi, E. Bernobich, M. Bonavita, G. Bertola, R. Trevisan, and G. Bellini, "Antihypertensive treatment with enrasentan (SB217242) in an animal model of hypertension and hyperinsulinemia," Journal of Cardiovascular Pharmacology, vol. 39, no. 4, pp. 488-495, 2002.

[84] P. Faure, E. Rossini, J. L. Lafond, M. J. Richard, A. Favier, and S. Halimi, "Vitamin E improves the free radical defense system potential and insulin sensitivity of rats fed high fructose diets," Journal of Nutrition, vol. 127, no. 1, pp. 103107, 1997.

[85] D. Song, S. Hutchings, and C. C. Y. Pang, "Chronic N-acetylcysteine prevents fructose-induced insulin resistance and 
hypertension in rats," European Journal of Pharmacology, vol. 508, no. 1-3, pp. 205-210, 2005.

[86] D. Galipeau, E. Arikawa, I. Sekirov, and J. H. McNeill, "Chronic thromboxane synthase inhibition prevents fructose-induced hypertension," Hypertension, vol. 38, no. 4, pp. 872-876, 2001.

[87] A. W. Miller, C. D. Tulbert, and D. W. Busija, "Rosuvastatin treatment reverses impaired coronary artery vasodilation in fructose-fed, insulin-resistant rats," American Journal of Physiology, vol. 287, pp. R157-R160, 2004.

[88] H. Vasudevan, P. R. Nagareddy, and J. H. McNeill, “Gonadectomy prevents endothelial dysfunction in fructose-fed male rats, a factor contributing to the development of hypertension," American Journal of Physiology, vol. 291, no. 6, pp. H3058-H3064, 2006.

[89] D. Song, E. Arikawa, D. Galipeau, M. Battell, and J. H. McNeill, "Androgens are necessary for the development of fructose-induced hypertension," Hypertension, vol. 43, no. 3, pp. 667-672, 2004.

[90] H. Vasudevan, H. Xiang, and J. H. McNeill, "Differential regulation of insulin resistance and hypertension by sex hormones in fructose-fed male rats," American Journal of Physiology, vol. 289, no. 4, pp. H1335-H1342, 2005.

[91] C. Zhao, P. Wang, X. Xiao et al., "Gene therapy with human tissue kallikrein reduces hypertension and hyperinsulinemia in fructose-induced hypertensive rats," Hypertension, vol. 42, no. 5, pp. 1026-1033, 2003.

[92] S. Verma, S. Bhanot, and J. H. McNeill, "Effect of chronic endothelin blockade in hyperinsulinemic hypertensive rats," American Journal of Physiology, vol. 269, no. 6, pp. H2017H2021, 1995.

[93] M. Fields and C. G. Lewis, "Dietary fructose but not starch is responsible for hyperlipidemia associated with copper deficiency in rats: effect of high-fat diet," Journal of the American College of Nutrition, vol. 18, no. 1, pp. 83-87, 1999.

[94] G. M. Reaven, H. Lithell, and L. Landsberg, "Hypertension and associated metabolic abnormalities - the role of insulin resistance and the sympathoadrenal system," New England Journal of Medicine, vol. 334, no. 6, pp. 374-381, 1996.

[95] G. M. Reaven and H. Chang, "Relationship between blood pressure, plasma insulin and triglyceride concentration, and insulin action in spontaneous hypertensive and Wistar-Kyoto rats," American Journal of Hypertension, vol. 4, no. 1, pp. 3438, 1991 .

[96] M. W. Brands, D. A. Hildebrandt, H. L. Mizelle, and J. E. Hall, "Sustained hyperinsulinemia increases arterial pressure in conscious rats," American Journal of Physiology, vol. 260, no. 4, pp. R764-R768, 1991.

[97] H. Abe, N. Yamada, K. Kamata et al., "Hypertension, hypertriglyceridemia, and impaired endothelium-dependent vascular relaxation in mice lacking insulin receptor substrate1," Journal of Clinical Investigation, vol. 101, no. 8, pp. 17841788, 1998.

[98] R. Tedde, L. A. Sechi, A. Marigliano, A. Pala, and L. Scano, "Antihypertensive effect of insulin reduction in diabetichypertensive patients," American Journal of Hypertension, vol. 2, no. 3, pp. 163-170, 1989.

[99] G. M. Reaven, "Abnormalities of carbohydrate and lipoprotein metabolism in patients with hypertension. Relationship to obesity," Annals of Epidemiology, vol. 1, no. 4, pp. 305-311, 1991.
[100] S. Rattigan, M. G. Clark, and E. J. Barrett, "Acute vasoconstriction-induced insulin resistance in rat muscle in vivo," Diabetes, vol. 48, no. 3, pp. 564-569, 1999.

[101] S. Rattigan, K. A. Dora, E. Q. Colquhoun, and M. G. Clark, "Inhibition of insulin-mediated glucose uptake in rat hindlimb by an $\alpha$-adrenergic vascular effect," American Journal of Physiology, vol. 268, no. 2, pp. E305-E311, 1995.

[102] S. Rattigan, K. A. Dora, E. Q. Colquhoun, and M. G. Clark, "Serotonin-mediated acute insulin resistance in the perfused rat hindlimb but not in incubated muscle: a role for the vascular system," Life Sciences, vol. 53, no. 20, pp. 1545-1555, 1993.

[103] D. B. Corry and M. L. Tuck, "Obesity, hypertension, and sympathetic nervous system activity," Current Hypertension Reports, vol. 1, no. 2, pp. 119-126, 1999.

[104] Y. J. Huang, V. S. Fang, C. C. Juan, Y. C. Chou, C. F. Kwok, and L. T. Ho, "Amelioration of insulin resistance and hypertension in a fructose-fed rat model with fish oil supplementation," Metabolism, vol. 46, no. 11, pp. 12521258, 1997.

[105] S. Verma, S. Bhanot, and J. H. McNeill, "Antihypertensive effects of metformin in fructose-fed hyperinsulinemic, hypertensive rats," Journal of Pharmacology and Experimental Therapeutics, vol. 271, no. 3, pp. 1334-1337, 1994.

[106] R. M. N. Bezerra, M. Ueno, M. S. Silva et al., "A high-fructose diet induces insulin resistance but not blood pressure changes in normotensive rats," Brazilian Journal of Medical and Biological Research, vol. 34, no. 9, pp. 1155-1160, 2001.

[107] M. W. Brands, C. A. Garrity, M. G. Holman, H. L. Keen, M. Alonso-Galicia, and J. E. Hall, "High-fructose diet does not raise 24-hour mena arterial pressure in rats," American Journal of Hypertension, vol. 7, no. 1, pp. 104-109, 1994.

[108] Y. Nishimoto, T. Tomida, H. Matsui, T. Ito, and K. Okumura, "Decrease in renal medullary endothelial nitric oxide synthase of fructose-fed, salt-sensitive hypertensive rats," Hypertension, vol. 40, no. 2, pp. 190-194, 2002.

[109] M. D. Johnson, H. Y. Zhang, and T. A. Kotchen, "Sucrose does not raise blood pressure in rats maintained on a low salt intake," Hypertension, vol. 21, no. 6, pp. 779-785, 1993.

[110] A. U. Ferrari, A. Daffonchio, F. Albergati, P. Bertoli, and G. Mancia, "Intra-arterial pressure alterations during tailcuff blood pressure measurements in normotensive and hypertensive rats," Journal of Hypertension, vol. 8, no. 10, pp. 909-911, 1990.

[111] P. Rosen, "Experimental benefit of moxonidine on glucose metabolism and insulin secretion in the fructose-fed rat," Journal of Hypertension, Supplement, vol. 15, no. 1, pp. S31S38, 1997.

[112] L. T. Tran, K. M. MacLeod, and J. H. McNeill, "Chronic etanercept treatment prevents the development of hypertension in fructose-fed rats," Molecular and Cellular Biochemistry, vol. 330, no. 1-2, pp. 219-228, 2009.

[113] R. Kobayashi, M. Nagano, F. Nakamura et al., "Role of angiotensin II in high fructose-induced left ventricular hypertrophy in rats," Hypertension, vol. 21, no. 6, pp. 10511055, 1993.

[114] R. A. DeFronzo, "The effect of insulin on renal sodium metabolism. A review with clinical implications," Diabetologia, vol. 21, no. 3, pp. 165-171, 1981.

[115] P. V. G. Katakam, M. R. Ujhelyi, M. E. Hoenig, and A. W. Miller, "Endothelial dysfunction precedes hypertension in 
diet-induced insulin resistance," American Journal of Physiology, vol. 275, no. 3, pp. R788-R792, 1998.

[116] S. Verma, S. Bhanot, L. Yao, and J. H. McNeill, "Defective endothelium-dependent relaxation in fructose-hypertensive rats," American Journal of Hypertension, vol. 9, no. 4, pp. 370 376, 1996.

[117] C. C. Juan, V. S. Fang, Y. P. Hsu et al., "Overexpression of vascular endothelin-1 and endothelin-A receptors in a fructoseinduced hypertensive rat model," Journal of Hypertension, vol. 16, no. 12, pp. 1775-1782, 1998.

[118] S. Verma, P. Skarsgard, S. Bhanot, L. Yao, I. Laher, and J. H. McNeill, "Reactivity of mesenteric arteries from fructose hypertensive rats to endothelin-1," American Journal of Hypertension, vol. 10, no. 9, pp. 1010-1019, 1997.

[119] W. P. Meehan, T. A. Buchanan, and W. Hsueh, "Chronic insulin administration elevates blood pressure in rats," Hypertension, vol. 23, no. 6, pp. 1012-1017, 1994.

[120] P. S. Hsieh and W. C. Huang, "Chemical sympathectomy attenuates hyperinsulinemia-induced hypertension in conscious rats," Nutrition, Metabolism \& Cardiovascular Diseases, vol. 3, pp. 173-178, 1993.

[121] M. Masai, Y. Fujioka, M. Fujiwara et al., "Activation of $\mathrm{Na}+/ \mathrm{H}+$ exchanger is associated with hyperinsulinemia in borderline hypertensive rats," European Journal of Clinical Investigation, vol. 31, no. 3, pp. 193-200, 2001.

[122] S. Vasdev, V. Gill, S. Parai, and V. Gadag, "Fructoseinduced hypertension in Wistar-Kyoto rats: interaction with moderately high dietary salt," Canadian Journal of Physiology and Pharmacology, vol. 85, no. 3-4, pp. 413-421, 2007.

[123] A. K. Singh, H. Amlal, P. J. Haas et al., "Fructose-induced hypertension: essential role of chloride and fructose absorbing transporters PAT1 and Glut5," Kidney International, vol. 74, no. 4, pp. 438-447, 2008.

[124] S. Barone, S. L. Fussell, A. K. Singh et al., "Slc2a5 (Glut5) is essential for the absorption of fructose in the intestine and generation of fructose-induced hypertension," Journal of Biological Chemistry, vol. 284, no. 8, pp. 5056-5066, 2009.

[125] Y. Takagawa, M. E. Berger, M. T. Hori, M. L. Tuck, and M. S. Golub, "Long-term fructose feeding impairs vascular relaxation in rat mesenteric arteries," American Journal of Hypertension, vol. 14, no. 8, pp. 811-817, 2001.

[126] K. Kamata and K. Yamashita, "Insulin resistance and impaired endothelium-dependent renal vasodilatation in fructose-fed hypertensive rats," Research Communications in Molecular Pathology and Pharmacology, vol. 103, no. 2, pp. 195-210, 1999.

[127] K. Shinozaki, K. Ayajiki, Y. Nishio, T. Sugaya, A. Kashiwagi, and T. Okamura, "Evidence for a causal role of the reninangiotensin system in vascular dysfunction associated with insulin resistance," Hypertension, vol. 43, no. 2, pp. 255-262, 2004.

[128] K. Shinozaki, Y. Nishio, T. Okamura et al., "Oral administration of tetrahydrobiopterin prevents endothelial dysfunction and vascular oxidative stress in the aortas of insulin-resistant rats," Circulation Research, vol. 87, no. 7, pp. 566-573, 2000.

[129] S. H. Carlson, J. Shelton, C. R. White, and J. M. Wyss, "Elevated sympathetic activity contributes to hypertension and salt sensitivity in diabetic obese Zucker rats," Hypertension, vol. 35, no. 1, pp. 403-408, 2000.

[130] S. Delbosc, E. Paizanis, R. Magous et al., "Involvement of oxidative stress and NADPH oxidase activation in the development of cardiovascular complications in a model of insulin resistance, the fructose-fed rat," Atherosclerosis, vol. 179 , no. 1, pp. 43-49, 2005.

[131] K. Kamata, N. Kanie, and A. Inose, "Mechanisms underlying attenuated contractile response of aortic rings to noradrenaline in fructose-fed mice," European Journal of Pharmacology, vol. 428, no. 2, pp. 241-249, 2001.

[132] P. V. Katakam, M. R. Ujhelyi, M. Hoenig, and A. W. Miller, "Metformin improves vascular function in insulin-resistant rats," Hypertension, vol. 35, no. 1, pp. 108-112, 2000.

[133] K. Shinozaki, A. Kashiwagi, Y. Nishio et al., "Abnormal biopterin metabolism is a major cause of impaired endothelium-dependent relaxation through nitric oxide/O2imbalance in insulin- resistant rat aorta," Diabetes, vol. 48, no. 12, pp. 2437-2445, 1999.

[134] T. W. Balon and J. L. Nadler, "Nitric oxide mediates skeletal glucose transport," American Journal of Physiology, vol. 270, no. 6, pp. E1058-E1059, 1996.

[135] U. Scherrer, D. Randin, P. Vollenweider, L. Vollenweider, and P. Nicod, "Nitric oxide release accounts for insulin's vascular effects in humans," Journal of Clinical Investigation, vol. 94, no. 6, pp. 2511-2515, 1994.

[136] K. Kuboki, Z. Y. Jiang, N. Takahara et al., "Regulation of endothelial constitutive nitric oxide synthase gene expression in endothelial cells and in vivo: a specific vascular action of insulin," Circulation, vol. 101, no. 6, pp. 676-681, 2000.

[137] S. Verma, S. Bhanot, L. Yao, and J. H. McNeill, "Vascular insulin resistance in fructose-hypertensive rats," European Journal of Pharmacology, vol. 322, no. 2-3, pp. R1-R2, 1997.

[138] C. Korandji, M. Zeller, J. C. Guilland et al., "Time course of asymmetric dimethylarginine (ADMA) and oxidative stress in fructose-hypertensive rats: a model related to metabolic syndrome," Atherosclerosis, vol. 214, no. 2, pp. 310-315, 2011.

[139] J. Busserolles, E. Gueux, E. Rock, A. Mazur, and Y. Rayssiguier, "Substituting honey for refined carbohydrates protects rats from hypertriglyceridemic and prooxidative effects of fructose," Journal of Nutrition, vol. 132, no. 11, pp. 33793382, 2002.

[140] M. Joyeux-Faure, E. Rossini, C. Ribuot, and P. Faure, "Fructose-fed rat hearts are protected against ischemiareperfusion injury," Experimental Biology and Medicine, vol. 231, no. 4, pp. 456-462, 2006.

[141] A. H. Polizio, S. Gonzales, M. C. Muñoz, C. Peña, and M. L. Tomaro, "Behaviour of the anti-oxidant defence system and heme oxygenase-1 protein expression in fructosehypertensive rats," Clinical and Experimental Pharmacology and Physiology, vol. 33, no. 8, pp. 734-739, 2006.

[142] A. T. A. Nandhini, V. Thirunavukkarasu, M. K. Ravichandran, and C. V. Anuradha, "Effect of taurine on biomarkers of oxidative stress in tissues of fructose-fed insulin-resistant rats," Singapore Medical Journal, vol. 46, no. 2, pp. 82-87, 2005.

[143] A. T. A. Nandhini, S. D. Balakrishnan, and C. V. Anuradha, "Response of liver antioxidant system to taurine in rats fed high fructose diet," Indian Journal of Experimental Biology, vol. 40, no. 9, pp. 1016-1019, 2002.

[144] A. Armenia, M. A. Sattar, N. A. Abdullah, M. A. Khan, and E. J. Johns, "Functional subtypes of renal $\alpha 1$-adrenoceptor in diabetic and non-diabetic 2K1C Goldblatt renovascular hypertension," Acta Pharmacologica Sinica, vol. 29, no. 5, pp. 564-572, 2008. 
[145] S. Takotori, Y. Zamami, M. Mio, Y. Kurosaki, and H. Kawasaki, "Chronic hyperinsulinemia enhances adrenergic vasoconstriction and decreases calcitonin gene-related peptide-containing nerve-mediated vasodilation in pithed rats," Hypertension Research, vol. 29, no. 5, pp. 361-368, 2006.

[146] R. V. Hogikyan and M. A. Supiano, "Arterial alphaadrenergic responsiveness is decreased and SNS activity is increased in older humans," American Journal of Physiology, vol. 266, no. 5, pp. E717-E724, 1994.

[147] C. L. J. Sun and J. P. Hanig, "Vascular reactivity to adrenergic agents and neuronal and vascular catecholamine levels in spontaneously hypertensive rats," Pharmacology, vol. 27, no. 6, pp. 319-324, 1983.

[148] P. Bunnag, M. T. Hori, B. Ormsby, M. E. Berger, M. S. Golub, and M. L. Tuck, "Impaired in vivo adrenergic responses in diet-induced hypertensive rats," Hypertension Research, vol. 20, no. 1, pp. 17-21, 1997.

[149] P. R. Tirupattur, J. L. Ram, P. R. Standley, and J. R. Sowers, "Regulation of $\mathrm{Na}+, \mathrm{K}+$-ATPase gene expression by insulin in vascular smooth muscle cells," American Journal of Hypertension, vol. 6, no. 7, pp. 626-629, 1993.

[150] A. M. Kahn, C. L. Seidel, J. C. Allen, R. G. O’Neil, H. Shelat, and T. Song, "Insulin reduces contraction and intracellular calcium concentration in vascular smooth muscle," Hypertension, vol. 22, no. 5, pp. 735-742, 1993.

[151] Y. Yoshida, M. Ohyanagi, and T. Iwasaki, "Chronological changes of $\alpha$-adrenoceptor-mediated vascular constriction in Otsuka-Long-Evans-Tokushima fatty rats," Hypertension Research, vol. 26, no. 7, pp. 559-567, 2003.

[152] R. O. B. Gans, H. J. G. Bilo, W. W. Maarschalkerweerd, R. J. Heine, J. J. P. Nauta, and A. J. M. Donker, "Exogenous insulin augments in healthy volunteers the cardiovascular reactivity to noradrenaline but not to angiotensin II," Journal of Clinical Investigation, vol. 88, no. 2, pp. 512-518, 1991.

[153] K. Sakai, T. Imaizumi, H. Masaki, and A. Takeshita, "Intraarterial infusion of insulin attenuates vasoreactivity in human forearm," Hypertension, vol. 22, no. 1, pp. 67-73, 1993.

[154] S. Yagi, S. Takata, H. Kiyokawa et al., "Effects of insulin on vasoconstrictive responses to norepinephrine and angiotensin II in rabbit femoral artery and vein," Diabetes, vol. 37, no. 8, pp. 1064-1067, 1988.

[155] W. D. Alexander and R. J. Oake, "The effect of insulin on vascular reactivity to norepinephrine," Diabetes, vol. 26, no. 7, pp. 611-614, 1977.

[156] D. W. Stepp, E. I. Boesen, J. C. Sullivan, J. D. Mintz, C. D. Hair, and D. M. Pollock, "Obesity augments vasoconstrictor reactivity to angiotensin II in the renal circulation of the Zucker rat," American Journal of Physiology, vol. 293, no. 4, pp. H2537-H2542, 2007.

[157] J. Pamidimukkala and B. S. Jandhyala, "Evaluation of hemodynamics, vascular reactivity and baroreceptor compensation in the insulin resistant Zucker obese rats," Clinical and Experimental Hypertension, vol. 18, no. 8, pp. 1089-1104, 1996.

[158] E. A. Anderson, R. P. Hoffman, T. W. Balon, C. A. Sinkey, and A. L. Mark, "Hyperinsulinemia produces both sympathetic neural activation and vasodilation in normal humans," Journal of Clinical Investigation, vol. 87, no. 6, pp. 2246-2252, 1991.

[159] M. S. Muntzel, E. A. Anderson, A. K. Johnson, and A. L. Mark, "Mechanisms of insulin action on sympathetic nerve activity," Clinical and Experimental Hypertension, vol. 17, no. 1-2, pp. 39-50, 1995.

[160] B. Bhagat, W. J. Burke, and N. S. Dhalla, "Insulin-induced enhancement of uptake of noradrenaline in atrial strips," British Journal of Pharmacology, vol. 74, no. 2, pp. 325-332, 1981.

[161] J. W. Rowe, J. B. Young, and K. L. Minaker, "Effect of insulin and glucose infusions on sympathetic nervous system activity in normal man," Diabetes, vol. 30, no. 3, pp. 219-225, 1981.

[162] M. Takagi, Y. Tanaka, Y. Yamasaki et al., "Responsiveness of insulin-induced cardiac sympathetic nerve activation associates with blood pressure regulation in diabetics," American Journal of Physiology, vol. 284, no. 5 47-5, pp. E1022-E1026, 2003.

[163] L. Landsberg, "Insulin and the sympathetic nervous system in the pathophysiology of hypertension," Blood Pressure, Supplement, vol. 5, no. 1, pp. 25-29, 1996.

[164] G. Lembo, R. Napoli, B. Capaldo et al., "Abnormal sympathetic overactivity evoked by insulin in the skeletal muscle of patients with essential hypertension," Journal of Clinical Investigation, vol. 90, no. 1, pp. 24-29, 1992.

[165] E. Isganaitis and R. H. Lustig, "Fast food, central nervous system insulin resistance, and obesity," Arteriosclerosis, Thrombosis, and Vascular Biology, vol. 25, no. 12, pp. 24512462, 2005.

[166] S. Obici, B. B. Zhang, G. Karkanias, and L. Rossetti, "Hypothalamic insulin signaling is required for inhibition of glucose production," Nature Medicine, vol. 8, no. 12, pp. 1376-1382, 2002.

[167] G. Grassi, "Sympathetic overdrive and cardiovascular risk in the metabolic syndrome," Hypertension Research, vol. 29, no. 11, pp. 839-847, 2006.

[168] G. Grassi, R. Dell'Oro, F. Quarti-Trevano et al., "Neuroadrenergic and reflex abnormalities in patients with metabolic syndrome," Diabetologia, vol. 48, no. 7, pp. 1359-1365, 2005.

[169] G. Grassi, "Role of the sympathetic nervous system in human hypertension," Journal of Hypertension, vol. 16, no. 12, pp. 1979-1987, 1998.

[170] A. Ylitalo, K. E. J. Airaksinen, K. U. O. Tahvanainen et al., "Baroreflex sensitivity in drug-treated systemic hypertension," American Journal of Cardiology, vol. 80, no. 10, pp. 1369-1372, 1997.

[171] F. Harrington, A. Murray, and G. A. Ford, "Relationship of baroreflex sensitivity and blood pressure in an older population," Journal of Hypertension, vol. 18, no. 11, pp. 1629-1633, 2000.

[172] L. L. Watkins, P. Grossman, and A. Sherwood, "Noninvasive assessment of baroreflex control in borderline hypertension: comparison with the phenylephrine method," Hypertension, vol. 28, no. 2, pp. 238-243, 1996.

[173] S. M. Pikkujämsä, H. V. Huikuri, K. E. J. Airaksinen et al., "Heart rate variability and baroreflex sensitivity in hypertensive subjects with and without metabolic features of insulin resistance syndrome," American Journal of Hypertension, vol. 11, no. 5, pp. 523-531, 1998.

[174] K. Lindgren, E. Hagelin, N. Hansén, and L. Lind, "Baroreceptor sensitivity is impaired in elderly subjects with metabolic syndrome and insulin resistance," Journal of Hypertension, vol. 24, no. 1, pp. 143-150, 2006.

[175] D. Ziegler, "Diabetic cardiovascular autonomic neuropathy: prognosis, diagnosis and treatment," Diabetes/Metabolism Reviews, vol. 10, no. 4, pp. 339-383, 1994. 
[176] D. L. Eckberg, S. W. Harkins, and J. M. Fritsch, "Baroreflex control of plasma norepinephrine and heart period in health subjects and diabetic patients," Journal of Clinical Investigation, vol. 78, no. 2, pp. 366-374, 1986.

[177] K. S. K. Chang and D. D. Lund, "Alterations in the baroreceptor reflex control of heart rate in streptozotocin diabetic rats," Journal of Molecular and Cellular Cardiology, vol. 18, no. 6, pp. 617-624, 1986.

[178] S. L. Stuesse, D. W. Wallick, and S. Mace, "Vagal control of heart period in alloxan diabetic rats," Life Sciences, vol. 31, no. 4, pp. 393-398, 1982.

[179] J. Ai, F. Liang, H. Zhou et al., "Mechanism of impaired baroreflex sensitivity in Wistar rats fed a high-fat and carbohydrate diet," British Journal of Nutrition, vol. 104, no. 2, pp. 291-297, 2010.

[180] G. B. Guo and F. M. Abboud, "Angiotensin II attenuates baroreflex control of heart rate and sympathetic activity," The American Journal of Physiology, vol. 246, no. 1, pp. H80-H89, 1984.

[181] K. P. Patel, C. A. Whiteis, D. D. Lund, and P. G. Schmid, "Effects of intravenous infusions of vasopressin and angiotensin II on central and peripheral noradrenergic function in conscious rabbits," Canadian Journal of Physiology and Pharmacology, vol. 65, no. 5, pp. 765-772, 1987.

[182] K. P. Patel and P. L. Zhang, "Baroreflex function in streptozotocin (STZ) induced diabetic rats," Diabetes Research and Clinical Practice, vol. 27, no. 1, pp. 1-9, 1995.

[183] A. E. Schutte, J. M. Van Rooyen, H. W. Huisman et al., "Modulation of baroreflex sensitivity by walnuts versus cashew nuts in subjects with metabolic syndrome," American Journal of Hypertension, vol. 19, no. 6, pp. 629-636, 2006.

[184] R. A. DeFronzo, C. R. Cooke, and R. Andres, "The effect of insulin on renal handling of sodium, potassium, calcium, and phosphate in man," Journal of Clinical Investigation, vol. 55, no. 4, pp. 845-855, 1975.

[185] P. Stenvinkel, A. Ottosson-Seeberger, and A. Alvestrand, "Renal hemodynamics and sodium handling in moderate renal insufficiency: the role of insulin resistance and dyslipidemia," Journal of the American Society of Nephrology, vol. 5, no. 10, pp. 1751-1760, 1995.

[186] M. Baum, "Insulin stimulates volume absorption in the rabbit proximal convoluted tubule," Journal of Clinical Investigation, vol. 79, no. 4, pp. 1104-1109, 1987.

[187] B. Mandon, E. Siga, D. Chabardes, D. Firsov, N. Roinel, and C. De Rouffignac, "Insulin stimulates $\mathrm{Na}+, \mathrm{Cl}-, \mathrm{Ca} 2+$, and $\mathrm{Mg} 2+$ transports in TAL of mouse nephron: crosspotentiation with AVP," American Journal of Physiology, vol. 265, no. 3, pp. F361-F369, 1993.

[188] J. C. Ter Maaten, S. J. L. Bakker, E. H. Semé, P. M. ter Wee, A. J. M. Donker, and R. O. B. Gans, "Insulin's acute effects on glomerular filtration rate correlate with insulin sensitivity whereas insulin's acute effects on proximal tubular sodium reabsorption correlate with salt sensitivity in normal subjects," Nephrology Dialysis Transplantation, vol. 14, no. 10, pp. 2357-2363, 1999.

[189] M. W. Brands, W. F. Lee, H. L. Keen, M. Alonso-Galicia, D. H. Zappe, and J. E. Hall, "Cardiac output and renal function during insulin hypertension in Sprague-Dawley rats," American Journal of Physiology, vol. 271, no. 1, pp. R276-R281, 1996.

[190] M. W. Brands, D. A. Hildebrandt, H. L. Mizelle, and J. E. Hall, "Hypertension during chronic hyperinsulinemia in rats is not salt-sensitive," Hypertension, vol. 19, no. 1, pp. I83-I89, 1992.

[191] A. T. A. Nandhini and C. V. Anuradha, "Hoe 140 abolishes the blood pressure lowering effect of taurine in high fructosefed rats," Amino Acids, vol. 26, no. 3, pp. 299-303, 2004.

[192] S. N. Iyer and M. J. Katovich, "Fructose feeding in rats is not associated with sodium retention," American Journal of Hypertension, vol. 9, no. 10, pp. 1018-1023, 1996.

[193] B. C. Kone and C. Baylis, "Biosynthesis and homeostatic roles of nitric oxide in the normal kidney," American Journal of Physiology, vol. 272, no. 5, pp. F561-F578, 1997.

[194] D. S. A. Majid, K. E. Said, S. A. Omoro, and L. G. Navar, "Nitric oxide dependency of arterial pressure-induced changes in renal interstitial hydrostatic pressure in dogs," Circulation Research, vol. 88, no. 3, pp. 347-351, 2001.

[195] A. W. Cowley Jr., D. L. Mattson, S. Lu, and R. J. Roman, “The renal medulla and hypertension," Hypertension, vol. 25, no. 4, pp. 663-673, 1995.

[196] H. Ikenaga, H. Suzuki, N. Ishii, H. Itoh, and T. Saruta, "Role of NO on pressure-natriuresis in Wistar-Kyoto and spontaneously hypertensive rats," Kidney International, vol. 43, no. 1, pp. 205-211, 1993.

[197] M. Barton, I. Vos, S. Shaw et al., "Dysfunctional renal nitric oxide synthase as a determinant of salt- sensitive hypertension: mechanisms of renal artery endothelial dysfunction and role of endothelin for vascular hypertrophy and glomerulosclerosis," Journal of the American Society of Nephrology, vol. 11, no. 5, pp. 835-846, 2000.

[198] C. F. Plato, E. G. Shesely, and J. L. Garvin, "eNOS mediates Larginine-induced inhibition of thick ascending limb chloride flux," Hypertension, vol. 35, no. 1, pp. 319-323, 2000.

[199] S. K. Park and T. W. Meyer, "The effects of fructose feeding on glomerular structure in the rat," Journal of the American Society of Nephrology, vol. 3, no. 6, pp. 1330-1332, 1992.

[200] N. Palanisamy, P. Viswanathan, and C. V. Anuradha, "Effect of genistein, a soy isof lavone, on whole body insulin sensitivity and renal damage induced by a high-fructose diet," Renal Failure, vol. 30, no. 6, pp. 645-654, 2008.

[201] T. Nakayama, T. Kosugi, M. Gersch et al., "Dietary fructose causes tubulointerstitial injury in the normal rat kidney," American Journal of Physiology, vol. 298, no. 3, pp. F712F720, 2010.

[202] M. H. Rault-Nania, C. Demougeot, E. Gueux et al., "Inulin supplementation prevents high fructose diet-induced hypertension in rats," Clinical Nutrition, vol. 27, no. 2, pp. 276-282, 2008.

[203] E. T. Koh, J. Mueller, O. Osilesi, A. Knehans, and S. Reiser, "Effects of fructose feeding on lipid parameters in obese and lean, diabetic and nondiabetic Zucker rats," Journal of Nutrition, vol. 115, no. 10, pp. 1274-1284, 1985.

[204] J. Manitius, A. D. Baines, and A. Roszkiewicz, "The effect of high fructose intake on renal morphology and renal function in rats," Journal of Physiology and Pharmacology, vol. 46, no. 2, pp. 179-183, 1995.

[205] H. K. Choi and G. Curhan, "Soft drinks, fructose consumption, and the risk of gout in men: prospective cohort study," British Medical Journal, vol. 336, no. 7639, pp. 309-312, 2008.

[206] J. W. J. Choi, E. S. Ford, X. Gao, and H. K. Choi, "Sugarsweetened soft drinks, diet soft drinks, and serum uric acid level: the Third National Health and Nutrition Examination Survey," Arthritis Care and Research, vol. 59, no. 1, pp. 109116, 2008. 
[207] D. A. Shoham, R. Durazo-Arvizu, H. Kramer et al., "Sugary soda consumption and albuminuria: results from the national health and nutrition examination survey, 19992004," PLos One, vol. 3, no. 10, Article ID e3431, 2008.

[208] P. Cirillo, M. S. Gersch, W. Mu et al., "Ketohexokinasedependent metabolism of fructose Induces proinflammatory mediators in proximal tubular cells," Journal of the American Society of Nephrology, vol. 20, no. 3, pp. 545-553, 2009.

[209] K. Yoshida, M. Kohzuki, H. L. Xu, X. M. Wu, M. Kamimoto, and T. Sato, "Effects of troglitazone and temocapril in spontaneously hypertensive rats with chronic renal failure," Journal of Hypertension, vol. 19, no. 3, pp. 503-510, 2001.

[210] S. Roysommuti, T. Khongnakha, D. Jirakulsomchok, and J. M. Wyss, "Excess dietary glucose alters renal function before increasing arterial pressure and inducing insulin resistance," American Journal of Hypertension, vol. 15, no. 9, pp. 773-779, 2002.

[211] A. Cosenzi, E. Bernobich, M. Bonavita, F. Gris, G. Odoni, and G. Bellini, "Role of nitric oxide in the early renal changes induced by high fructose diet in rats," Kidney and Blood Pressure Research, vol. 25, no. 6, pp. 363-369, 2002.

[212] N. Sharma, I. C. Okere, M. K. Duda et al., "High fructose diet increases mortality in hypertensive rats compared to a complex carbohydrate or high fat diet," American Journal of Hypertension, vol. 20, no. 4, pp. 403-409, 2007. 


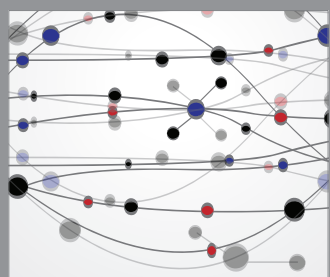

The Scientific World Journal
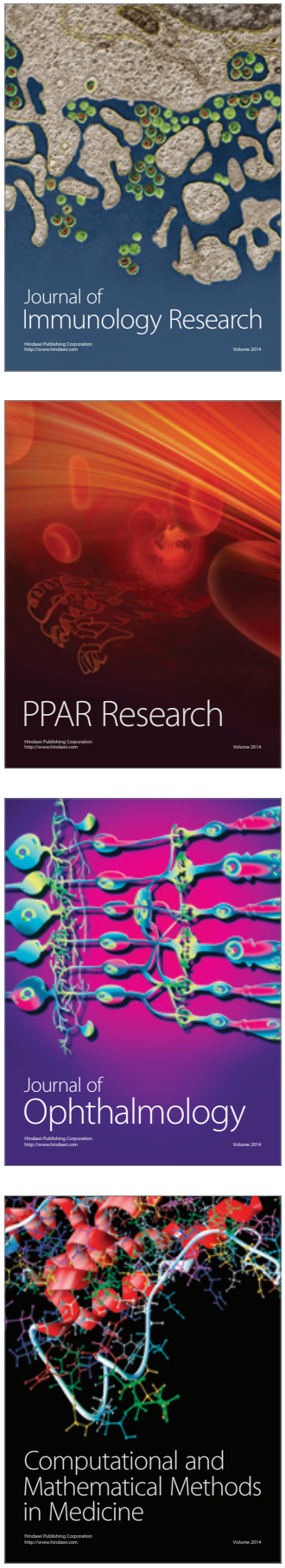

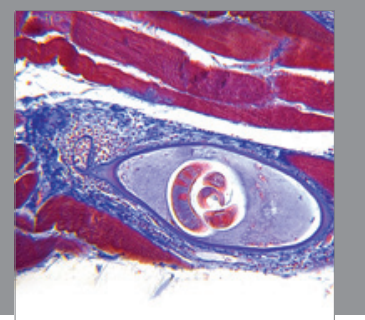

Gastroenterology

Research and Practice
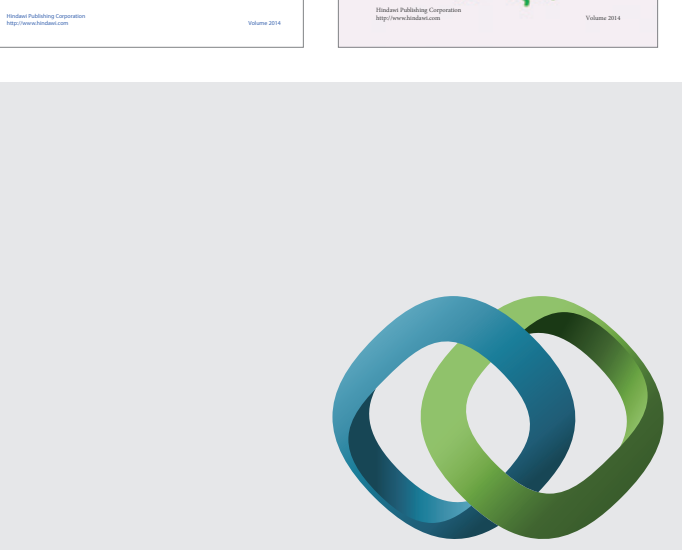

\section{Hindawi}

Submit your manuscripts at

http://www.hindawi.com
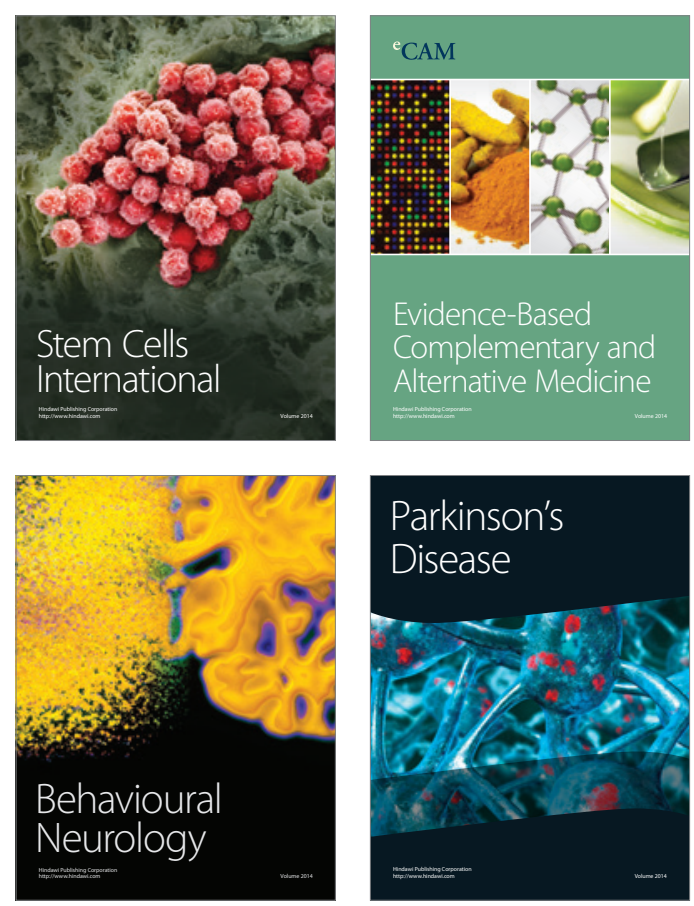

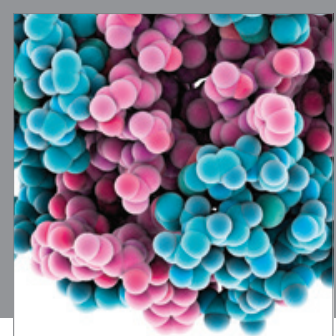

Journal of
Diabetes Research

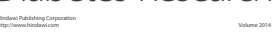

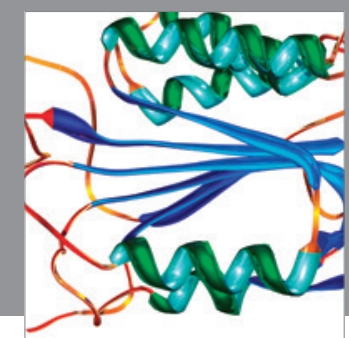

Disease Markers
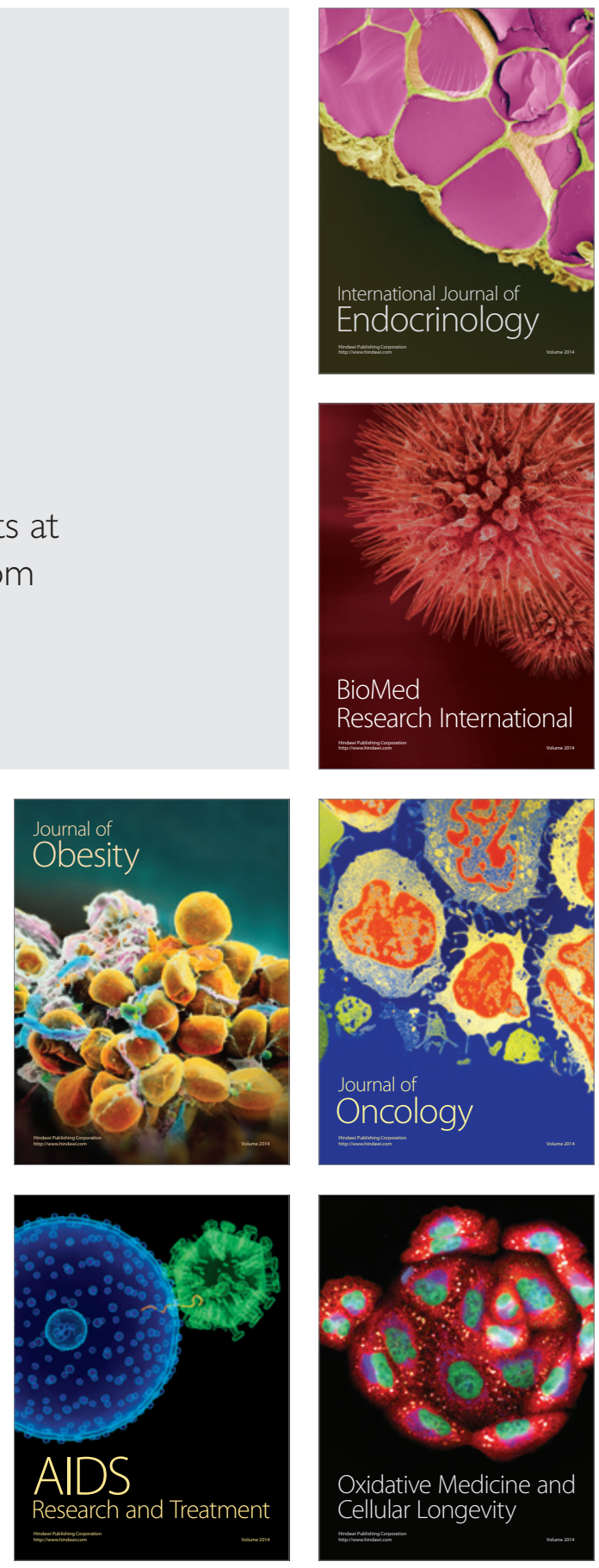